\title{
Markers for the Comparison of the Performances of Anoxic Biotrickling Filters in Biogas Desulphurisation: A Critical Review
}

\author{
Emky Valdebenito-Rolack ${ }^{1,2,3, *(D)}$, Rosario Díaz ${ }^{1,2,3}$, Felipe Marín ${ }^{1,2}$, Daniel Gómez ${ }^{1,2}$ and Felipe Hansen ${ }^{1,2,3}$ (D) \\ 1 ProCycla SpA and SL, Camino Fundo El Junco SN, Melipilla 9580000, Región Metropolitana, Chile; \\ rdiaz@aroma.global (R.D.); fmarin@procycla.com (F.M.); dgomez@procycla.com (D.G.); \\ fhansen@procycla.com (F.H.) \\ 2 Carretera Pont de Vilomara 140, 2-1, 08241 Manresa, Spain \\ 3 Aroma SpA, Camino Fundo El Junco SN, Melipilla 9580000, Región Metropolitana, Chile \\ * Correspondence: evaldebenito@aroma.global
}

Citation: Valdebenito-Rolack, E. Díaz, R.; Marín, F.; Gómez, D.;

Hansen, F. Markers for the

Comparison of the Performances of Anoxic Biotrickling Filters in Biogas Desulphurisation: A Critical Review. Processes 2021, 9, 567. https:// doi.org/10.3390/pr9030567

Academic Editor: Pietro Bartocci

Received: 15 February 2021

Accepted: 21 March 2021

Published: 23 March 2021

Publisher's Note: MDPI stays neutral with regard to jurisdictional claims in published maps and institutional affiliations.

Copyright: (c) 2021 by the authors. Licensee MDPI, Basel, Switzerland. This article is an open access article distributed under the terms and conditions of the Creative Commons Attribution (CC BY) license (https:// creativecommons.org/licenses/by/ $4.0 /)$.

\begin{abstract}
The agriculture and livestock industry generate waste used in anaerobic digestion to produce biogas containing methane $\left(\mathrm{CH}_{4}\right)$, useful in the generation of electricity and heat. However, although biogas is mainly composed of $\mathrm{CH}_{4}(\sim 65 \%)$ and $\mathrm{CO}_{2}(\sim 34 \%)$, among the $1 \%$ of other compounds present is hydrogen sulphide $\left(\mathrm{H}_{2} \mathrm{~S}\right)$ which deteriorates engines and power generation fuel cells that use biogas, generating a foul smell and contaminating the environment. As a solution to this, anoxic biofiltration, specifically with biotrickling filters (BTFs), stands out in terms of the elimination of $\mathrm{H}_{2} \mathrm{~S}$ as it is cost-effective, efficient, and more environmentally friendly than chemical solutions. Research on the topic is uneven in terms of presenting performance markers, underestimating many microbiological indicators. Research from the last decade was analyzed (2010-2020), demonstrating that only $56 \%$ of the reviewed publications did not report microbiological analysis related to sulphur oxidising bacteria (SOB), the most important microbial group in desulphurisation BTFs. This exposes fundamental deficiencies within this type of research and difficulties in comparing performance between research works. In this review, traditional and microbiological performance markers of anoxic biofiltration to remove $\mathrm{H}_{2} \mathrm{~S}$ are described. Additionally, an analysis to assess the efficiency of anoxic BTFs for biogas desulphurisation is proposed in order to have a complete and uniform assessment for research in this field.
\end{abstract}

Keywords: anoxic biofiltration; hydrogen sulphide; desulphurisation; biotrickling filtration; biofilter performance

\section{Introduction}

Anaerobic digestion (AD) is a biological process where solid organic matter originated in the agriculture and livestock industry, among others, is used to obtain biogas containing methane $\left(\mathrm{CH}_{4}\right)$, which in quantities of $\sim 65 \%$ is burned to produce bioenergy as heat and electricity in cogeneration engines [1]. The world's biggest waste sources used in AD come from rice farming, corn farming, and wheat. Among them, the major energy crops for biogas production are maize silage and grass, followed by lignocellulosic residues or other plant biomass in general (rich in lignin content) from sources such as banana plants (leftover banana trees, flowers, leaves), palm oil residues after harvest, sugar and palm oil refinement processes (that produce large quantities of fibrous lignocellulosic biomass), forestry residues, coffee pulp, and field residues such as corn stover [2]. AD is conducted by breaking up the organic matter (anaerobically) generating biogas, mainly composed of methane $\left(\mathrm{CH}_{4}\right)$ and carbon dioxide $\left(\mathrm{CO}_{2}\right)$, with a lower concentration of hydrogen sulphide $\left(\mathrm{H}_{2} \mathrm{~S}\right)$, ammonium $\left(\mathrm{NH}_{3}\right)$, and other trace compounds [1].

$\mathrm{AD}$ is carried out by several groups of bacteria and methanogenic archaea in four stages: hydrolysis, acidogenesis, acetogenesis, and methanogenesis, $\mathrm{CH}_{4}$ is produced in the last stage [1]. In the intermediate stages of $\mathrm{AD}, \mathrm{H}_{2} \mathrm{~S}$ is produced from the degradation 
of proteins containing sulphur-rich amino acids and from the sulphate reduction $\left(\mathrm{SO}_{4}{ }^{2-}\right)$. This process is carried out by sulphate-reducing bacteria (SRB) [3].

At low concentrations $\left(0.01-0.3 \mathrm{ppm}_{\mathrm{v}}\right) \mathrm{H}_{2} \mathrm{~S}$ produces foul smells and the effects of $\mathrm{H}_{2} \mathrm{~S}$ on human health at different concentrations are summarized in Table 1 . Thus, the maximum exposure concentration permitted in the industry is $10 \mathrm{ppm}_{\mathrm{V}}$, with peaks of $50 \mathrm{ppm}_{\mathrm{v}}$ accepted for a duration of $10 \mathrm{~min}[4,5]$.

Table 1. $\mathrm{H}_{2} \mathrm{~S}$ concentrations and subsequent effects on human health [4].

\begin{tabular}{cl}
\hline $\mathbf{H}_{\mathbf{2}} \mathbf{S}$ Concentration $\left(\mathbf{p p m}_{\mathbf{v}}\right)$ & \multicolumn{1}{c}{ Effect on Human Health } \\
\hline $0.01-0.3$ & Olfactory threshold. Rotten egg smell. \\
20 & Strong odour. Eye irritation may occur. \\
$20-50$ & $\begin{array}{l}\text { Eye and lung irritation. } \\
\text { Eye and lung irritation, olfactory paralysis, apparent } \\
100\end{array}$ \\
$>150$ & disappearance of odour. \\
$>250$ & Severe eye and lung irritation. Sensation of olfactory loss. \\
$>500$ & Pulmonary edema and risk of death. \\
$>1000$ & Highly dangerous, risk of death. Evacuation is mandatory. \\
& Loss of consciousness, apnoea, immediate collapse. Death. \\
\hline
\end{tabular}

During biogas combustion for the production of heat or electricity in cogeneration units, the co-combustion of the $\mathrm{H}_{2} \mathrm{~S}$ content produces sulphur dioxide $\left(\mathrm{SO}_{2}\right)$ emissions which cause acid rain [6]. Furthermore, at concentrations over $500 \mathrm{ppm}_{\mathrm{v}} \mathrm{H}_{2} \mathrm{~S}$ corrodes metals and degrades engine oil in the cogeneration units where biogas is burned to generate electrical power, producing malfunction [7-9]. For the use of biogas in combustion for the generation of heat, concentrations of up to $200-500 \mathrm{ppm}_{\mathrm{v}}$ are accepted, but preferably this should be zero [10].

Another use of biogas affected by its $\mathrm{H}_{2} \mathrm{~S}$ content is in the application of biogas as a raw material for high-efficiency fuel cells, especially solid-oxide fuel cells (SOFC) where electricity is generated by electrochemical reactions with low contaminant emissions [11]. For instance, in conventional SOFCs with nickel anodes, $\mathrm{H}_{2} \mathrm{~S}$ forms a nickel sulphide precipitate (NiS) creating a metal sulphide layer on the anode surface, reducing the cell electrochemical activity [12]. The effect of $\mathrm{H}_{2} \mathrm{~S}$ on the anodes depends on the SOFC materials and the operating temperature. Thus, it has been reported that in cells with nickel-yttria stabilized zirconia (NiYSZ), scandium-stabilized zirconia (Ni-ScSZ), and nickel-gadolinium-doped-ceria (Ni-GDC) a harmful effect on the anode occurs at $>5-20$ ppm $_{\mathrm{V}}[12]$.

The aforementioned corrosion of electricity cogeneration units and the international regulations referring to $\mathrm{H}_{2} \mathrm{~S}$ concentrations prior to biomethane injection into natural gas grids (among others) have motivated the development of many physical-chemical and biological methods for eliminating $\mathrm{H}_{2} \mathrm{~S}$ in biogas [13]. The first methods include technologies based on in-situ chemical precipitation, absorption, and membrane separation [13]. The latter refer to biofilters, which stand out because they are cost-effective, efficient, and more environmentally friendly than physical-chemical methods [14]. Biofilters for gas treatment are devices in which a residual gas current containing pollutants is passed through a packing material containing bacteria immobilized as biofilms capable of metabolizing the pollutants (like $\mathrm{H}_{2} \mathrm{~S}$ in biogas) [15]. There are two groups of biofilters: (1) open biofilters: usually a box with packing material containing the biofilms inside which is open to the atmosphere, in which parameters such as temperature, humidity, and the purity of the microbial cultures are difficult to control as they are weather dependent (due to rain and temperature fluctuation, among others); and (2) closed biofilters: in which the biofilmcontaining packing material is inside a closed container (usually made of steel or plastic), making it easier to control parameters such as culture media flow, nutrients, gas flow, temperature, and humidity [16]. Biofiltration is considered more environmentally and economically friendly than physical-chemical methods, as it requires significantly lower chemical use and energy consumption, which translates into a low carbon footprint and 
lower costs [14]. Thus, $\mathrm{H}_{2} \mathrm{~S}$ biofiltration has been researched since the early 1990s [17], being of greater interest in recent years [18]. Biotrickling filters (BTF) are a type of closed biofilter combined with a bioreactor containing a microorganisms culture or a nutrient solution container. These filters are different to other biological solutions such as bioscrubbers as they contain packing material in the biofiltration section, while for bioscrubbers the biofiltration is undertaken in two stages: firstly, a column containing a liquid culture to absorb the pollutant is used and then a bioreactor is used in order to carry out the pollutant degradation [19]. BTFs are one of the most widely used biological technologies to perform biogas desulfurisation, because of their lower investment, operation, and maintenance costs, as well as for their greater energy efficiency, both in the removal of foul smells and in industrial-scale applications for biogas treatment $[20,21]$. Furthermore, this type of biotechnology presents a low pressure drop and an equitable distribution of microorganisms through the biofilter bed of the BTF [22]. Due to these factors, we henceforth focus our discussion on BTFs.

Although research on biofiltration to remove $\mathrm{H}_{2} \mathrm{~S}$ is extensive, the results are often unevenly reported, making it difficult to compare the efficiency of BTFs and neglecting the microorganisms used (Table 2). There are almost as many ways to express biofiltration performance markers as there are research works on them. In some cases only $\mathrm{H}_{2} \mathrm{~S}$ inlet and outlet concentrations of the biofilter or BTF were reported, without taking into account the type and concentration of microorganisms that performed the degradation, as described in the Table 2, in the research items 8, 9, 13, 14, and 15. For example, Brito et al. (2018) evaluated the change of nitrate $\left(\mathrm{NO}_{3}{ }^{-}\right)$to nitrite $\left(\mathrm{NO}_{2}{ }^{-}\right)$as electron acceptors in BTFs for $\mathrm{H}_{2} \mathrm{~S}$ removal, only reporting the outlet $\mathrm{H}_{2} \mathrm{~S}$ concentration ( $15 \mathrm{ppm}_{\mathrm{v}}$ ), describing loading rates (LR) from 7-69 $\mathrm{g} \mathrm{m}^{-3} \mathrm{~h}^{-1}$. However, it would be more insightful to have a performance comparison on critical and maximal elimination capacities (ECs) and their respective removal efficiencies (REs), specifically if the LRs was given [23]. In other cases, different operational conditions of the BTFs were compared through the indicators' removal efficiencies (REs), empty bed residence times (EBRTs), ECs, and $\mathrm{H}_{2} \mathrm{~S}$ LRs, as described in the Table 2, in the research items $1,2,3,4,5,6,7,10,11,12,16,17$, and 18 . Today these markers are considered traditional parameters of biofiltration efficiency, referring to the process carried out in biofilters or BTFs indistinctly [24]. Some works, such as Valle et al. (2018), have focused on the analysis of the BTF microbiota and the RE, but they did not report on other important biofiltration performance markers, such EC, and other parameters like EBRT can only be calculated or inferred by the reader based on the presented data [25]. In the same way, most of the research cited in this review only reports the critical indicators (like $\mathrm{EC}_{\text {crit }}$ ) or the maximal markers (like $\mathrm{EC}_{\max }$ ) and they are not the same (see Section 3). One of the reviewed works, Almenglo et al. (2016), reported on both the critical and maximal performance markers, indicating an $\mathrm{EC}_{\text {crit }}$ of $94.7 \mathrm{~g} \mathrm{~m}^{-3} \mathrm{~h}^{-1}$ with a respective $\mathrm{RE}>99 \%$ and an $\mathrm{EC}_{\max }$ of $127.3 \mathrm{~g} \mathrm{~m}^{-3} \mathrm{~h}^{-1}$ with an $\mathrm{RE}=92.6 \%$ [26]. Although it is true that the study of traditional efficiency parameters is the most practical way to compare different operational scenarios in biofiltration, it is also important to investigate the speed at which the inoculated microorganisms colonize the packing material used and draw a relationship between the biomass of the formed biofilm and the $\mathrm{H}_{2} \mathrm{~S}$ concentration that the biofiltration device is capable of removing. This will be an indicator that the species, strain, or microbial community used is more or less efficient (for which taxonomic identification will be convenient) and will allow the selection of microorganisms and packing materials suitable in preventing clogging by biomass or elemental sulphur accumulation, a collateral effect that reduces the efficiency of the device producing pressure drops in the long term $[27,28]$. For example, Fernández et al. (2012) compared two BTFs, one packed with open polyurethane foam (BTHE) and the other with polypropylene pall rings (BTHA), both inoculated with a strain (DSM 12475) of the sulphur-oxidizing bacteria Thiobacillus thioparus. This research group observed that the BTHE EC $\left(22 \mathrm{~g} \mathrm{H}_{2} \mathrm{~S} \mathrm{~m}^{-3} \mathrm{~h}^{-1}\right)$ was higher than the BTHA EC $\left(12 \mathrm{~g} \mathrm{H}_{2} \mathrm{~S} \mathrm{~m}^{-3} \mathrm{~h}^{-1}\right)$, finding that for the BTHA the biomass was 1 log less $\left(1.96 \times 10^{9} \text { cells (g dry carrier) }\right)^{-1}$, suggesting that the higher performance of BTHE was 
caused by its greater immobilized biomass and, despite the higher EC of BTHE, this BTF will be clogged sooner than the one containing BTHA [29]. On the other hand, Tayar et al. (2019) evaluated the immobilized biomass of an impure microbial inoculum (anaerobic sludge) in different polymeric packing materials of BTFs, such polyvinyl chloride (PVC) and open-pore polyurethane foam (OPUF), among others, finding that the PVC BTF produced an EC six times higher than that of the OPUF $\left(84.4 \mathrm{gS} \mathrm{H}_{2} \mathrm{~S} \mathrm{~m}^{-3} \mathrm{~h}^{-1}\right.$ and $14 \mathrm{gS} \mathrm{H}_{2} \mathrm{~S}$ $\mathrm{m}^{-3} \mathrm{~h}^{-1}$, respectively) in view of the fact that the biomass immobilized in the PVC was $\sim 1.7$ times less than that of the OPUF ( 15 and $~ 25.4$ mass of protein per mass of dry support $\left(\mathrm{mg} \mathrm{g}^{-1}\right)$, respectively) and with the advantage that PVC is cheaper than OPUF [30]. In addition, this is a topic that is closely related to the material chosen to develop the bacterial biofilms in the BTF, demonstrating that the biomass immobilization tests in addition to the EC testing are useful in the selection of suitable packing materials [18]. The problem is that research on anoxic biogas filtration to remove $\mathrm{H}_{2} \mathrm{~S}$ has focused on one of these three topics: (a) the concentrations removed by the BTF, (b) the traditional removal parameters (RE, LR, EBRT, and EC) or, (c) the BTF microbial ecology. However, the behaviour of a BTF is the sum of the three aspects described above and they must be analysed as a whole. Few investigations include the three factors mentioned before. In fact, it has been recently described that the device technical characteristics, gas flow (Q), traditional biofiltration parameters, types of microorganisms used, and type of culture medium must be adequately correlated to establish robust conclusions about the behaviour of a biofiltration system [16]. In view of all this, standardization of the results presentation in biofiltration to remove $\mathrm{H}_{2} \mathrm{~S}$ from biogas or for any type of gas BTF research, is of vital importance. Similarly, it is also important to determine the concentration and identity of the microorganisms used. Because of this, the objectives of this article are: (a) to review the traditional efficiency and microbiological markers in BTFs and the correct presentation of them; (b) to describe the microbiological analyses that are convenient for performance in the biotrickling filter study; (c) to review the status of BTFs for biogas $\mathrm{H}_{2} \mathrm{~S}$ anoxic removal in the recent decade (2010-2020), with emphasis on the research comparison as per the traditional and microbiological markers; and (d) to propose a performance markers framework for the comparison of BTF research that every study in the field should use. 
Table 2. Research on anoxic biofiltration for biogas desulphurisation from 2010 to 2020.

\begin{tabular}{|c|c|c|c|c|c|c|c|c|c|c|c|c|c|c|c|}
\hline BTF Scale & $\left(\mathrm{H}_{2} \mathrm{~S}\right)\left(\mathrm{ppm}_{\mathrm{v}}\right)$ & $\begin{array}{c}\mathbf{L R}_{\text {crit }} \\
\left(\mathrm{g} \mathrm{m}^{-3}\right. \\
\left.\mathrm{h}^{-1}\right) \\
\end{array}$ & $\begin{array}{c}\mathrm{EC}_{\text {crit }} \\
\left(\mathrm{g} \mathrm{m}^{-3}\right. \\
\left.\mathbf{h}^{-1}\right) \\
\end{array}$ & $\begin{array}{c}\mathrm{RE}_{\text {crit }} \\
(\%)\end{array}$ & $\begin{array}{l}\text { EBRT for } \\
\text { EC } \text { crit } \\
\text { (min) }\end{array}$ & $\begin{array}{c}\mathrm{EC}_{\max } \\
\left(\mathrm{g} \mathrm{m}^{-3}\right. \\
\left.\mathrm{h}^{-1}\right) \\
\end{array}$ & $\underset{(\%)}{\mathrm{RE}_{\max }}$ & $\begin{array}{l}\text { EBRT for } \\
\text { EC } \max \\
\text { (min) }\end{array}$ & $\mathrm{pH}$ & $\mathrm{T}\left({ }^{\circ} \mathrm{C}\right)$ & $\begin{array}{l}{\left[\mathrm{NO}_{3}^{-}\right]} \\
\left(\mathrm{g} \mathrm{L}^{-1}\right)\end{array}$ & $\begin{array}{l}\text { TLF/TLV at } \mathrm{EC}_{\text {crit }} \\
\left(\mathrm{L} \mathrm{min}^{-1 /} \mathrm{m} \mathrm{h}^{-1}\right)\end{array}$ & $\begin{array}{c}\text { Inoculum/Packing } \\
\text { Material }\end{array}$ & $\begin{array}{l}\text { Microbial } \\
\text { Analysis }\end{array}$ & Ref. \\
\hline (1) Lab scale & $60-4000$ & 22 & 22 & 99 & ND & ND & ND & ND & $7.3-7.5$ & ND & ND & ND & $\begin{array}{l}\text { Thiobacillus denitrificans } \\
\text { DSM 12475/OPUF }\end{array}$ & DGGE & [29] \\
\hline (3) Lab scale & $1400-14,600$ & 120 & 120 & 99 & 3 & 170 & $\sim 95$ & 17 & $7-4$ & $28-30$ & $5-10$ & $2.2 / 15$ & $\begin{array}{c}\text { Community of } \\
\text { microorganisms from } \\
\text { WWTP sludge, selected } \\
\text { in the BTF/PPR }\end{array}$ & DGGE & [32] \\
\hline (5) Lab scale & $850-8500$ & 130 & 130 & 99 & 2.4 & 170 & 85 & 2.4 & $7.3-7.5$ & 30 & 5 & $\mathrm{ND} />4.6$ & $\begin{array}{l}\text { Consortium from a } \\
\text { stirred tank reactor of an } \\
\text { WWTP/OPUF cubes }\end{array}$ & ND & [34] \\
\hline (6) Pilot scale & $4100-7100$ & 56 & 56 & 98 & 2 & 140 & 84 & 10 & $6.8-7.5$ & ND & $1.6-4$ & $32.7 / 10$ & $\begin{array}{l}\text { Community of } \\
\text { microorganisms from } \\
\text { wastewater from the } \\
\text { degritter-degreasing, } \\
\text { selected in the } \\
\text { BTF/OPUF }\end{array}$ & $\begin{array}{l}\text { 16S rDNA } \\
\text { Pyrosequencing } \\
\text { (TEFAP) }\end{array}$ & [35] \\
\hline (8) Lab scale & $4400-8000$ & 26.2 & 26.2 & 99.1 & 30 & ND & ND & ND & 7 & 25 & 3 & ND & $\begin{array}{l}\text { Microbial consortia from } \\
\text { sludge of an upflow } \\
\text { anaerobic sludge blanket } \\
\text { reactor from poultry } \\
\text { slaughterhouse/PU foam }\end{array}$ & ND & [36] \\
\hline (9) Lab scale & 1500-1600 & 16.3 & 54.5 & 99 & $2-5$ & ND & ND & ND & $6-7.5$ & 25 & $0.2-0.7$ & $0.005-0.010 / \mathrm{ND}$ & $\begin{array}{l}\text { Microbial enrichment } \\
\text { from anaerobic sludge } \\
\text { from a WWTP/PP rings }\end{array}$ & ND & [37] \\
\hline
\end{tabular}


Table 2. Cont.

\begin{tabular}{|c|c|c|c|c|c|c|c|c|c|c|c|c|c|c|c|}
\hline BTF Scale & $\left(\mathrm{H}_{2} \mathrm{~S}\right)\left(\mathrm{ppm}_{\mathrm{v}}\right)$ & $\begin{array}{l}\mathbf{L R}_{\text {crit }} \\
\left(\mathrm{g} \mathrm{m}^{-3}\right. \\
\left.\mathbf{h}^{-1}\right)\end{array}$ & $\begin{array}{c}\mathrm{EC}_{\text {crit }} \\
\left(\mathrm{g} \mathrm{m}^{-3}\right. \\
\left.\mathrm{h}^{-1}\right)\end{array}$ & $\begin{array}{l}\mathrm{RE}_{\text {crit }} \\
(\%)\end{array}$ & $\begin{array}{l}\text { EBRT for } \\
\text { EC }_{\text {crit }} \\
\text { (min) }\end{array}$ & $\begin{array}{l}\mathrm{EC}_{\max } \\
\left(\mathrm{g} \mathrm{m}^{-3}\right. \\
\left.\mathrm{h}^{-1}\right)\end{array}$ & $\underset{(\%)}{\mathrm{RE}_{\max }}$ & $\begin{array}{l}\text { EBRT for } \\
\text { EC } \max \\
\text { (min) }\end{array}$ & $\mathrm{pH}$ & $\mathrm{T}\left({ }^{\circ} \mathrm{C}\right)$ & $\begin{array}{l}{\left[\mathrm{NO}_{3}^{-}\right]} \\
\left(\mathrm{g} \mathrm{L}^{-1}\right)\end{array}$ & $\begin{array}{l}\text { TLF/TLV at EC } \text { crit }_{\text {. }} \\
\left(\mathrm{L} \mathrm{min}^{-1 /} \mathrm{m} \mathrm{h}^{-1}\right)\end{array}$ & $\begin{array}{c}\text { Inoculum/Packing } \\
\text { Material }\end{array}$ & $\begin{array}{l}\text { Microbial } \\
\text { Analysis }\end{array}$ & Ref. \\
\hline (10) Field scale & ND & 438 & 438 & ND & ND & 1509 & 99.8 & 54-107 & $3-6.9$ & 21 & 0.7 & $1.17 / \mathrm{ND}$ & $\begin{array}{l}\text { Community of } \\
\text { microorganisms from } \\
\text { swine wastewater } \\
\text { selected in the BTF/PP } \\
\text { bioballs }\end{array}$ & $\begin{array}{l}\text { RT-PCR for } \\
\text { relevant } \\
\text { methanogens } \\
\text { detection not for } \\
\text { SOB }\end{array}$ & [38] \\
\hline (11) Pilot scale & 265-1245 & 1.79 & 1.79 & 99.3 & 12.3 & 8.45 & 96.4 & 12.3 & $6.2-6.9$ & $23-27$ & $0.42-1.26$ & $\mathrm{ND} / 1.02$ & $\begin{array}{l}\text { Microbial consortium } \\
\text { isolated from a mix of } \\
\text { sludge from anaerobic } \\
\text { fermentation chambers } \\
\text { and from chemical } \\
\text { desulfurization units/PE } \\
\text { K1 rings }\end{array}$ & $\begin{array}{l}\text { CFU count in } \\
\text { nutrient agar } \\
\text { plates }\end{array}$ & [39] \\
\hline (12) Lab scale & $900-1100$ & 25.2 & 25.2 & 100 & 2 & 30.3 & $\sim 95$ & 4,5 & 9,7 & ND & ND & ND & $\begin{array}{l}\text { Microorganisms of } \\
\text { activated sludge from a } \\
\text { domestic WWTP, selected } \\
\text { in the BTF/expanded } \\
\text { schist and cellular } \\
\text { concrete }\end{array}$ & ND & [40] \\
\hline (13) Lab scale & 1900 & 79.8 & 79.8 & ND & 117 & 141.1 & ND & 117 & 7.4 & $33-80$ & $0.13-0.3$ & $0.67 / 10$ & ND/PPR & ND & [41] \\
\hline (14) Lab scale & $710-3564$ & ND & ND & 94.7 & 2 & 141 & 94.7 & 2 & $7.4-7.5$ & 30 & 1.98 & $1 / 15$ & $\begin{array}{l}\text { Community of } \\
\text { microorganisms from a } \\
\text { sample of WWTP, } \\
\text { selected in the BTF/PP } \\
\text { rings }\end{array}$ & DGGE & [23] \\
\hline (15) Lab scale & 2848 & 80 & 80 & 96.5 & 1.96 & 141.1 & 92.9 & 1.96 & $7.4-7.5$ & ND & $\begin{array}{l}0.38- \\
0.418\end{array}$ & $\mathrm{ND} / 10$ & $\mathrm{ND} / \mathrm{PP}$ rings & ND & [42] \\
\hline (16) Lab scale & 2000 & 51.48 & ND & 98 & 2.2 & ND & ND & ND & $7.3-7.5$ & ND & 5 & $8.4-60 / 2.28-20.6$ & $\begin{array}{l}\text { Community of } \\
\text { microorganisms from a } \\
\text { stirred tank reactor of a } \\
\text { WWTP, selected in the } \\
\text { BTF/OPUF and PP rings }\end{array}$ & DGGE & [25] \\
\hline (17) Lab scale & $100-500$ & $\sim 16.4$ & $\sim 16.4$ & 91.9 & ND & 19.2 & 99 & 3.5 & 7 & 24 & $\begin{array}{l}0.012- \\
0.062\end{array}$ & $0.04 / 0.22$ & $\begin{array}{l}\text { Thiobacillus dominated } \\
\text { culture from a moving } \\
\text { bed biofilm reactor/PU } \\
\text { foam }\end{array}$ & DGGE & [43] \\
\hline
\end{tabular}


Table 2. Cont.

\begin{tabular}{|c|c|c|c|c|c|c|c|c|c|c|c|c|c|c|c|}
\hline BTF Scale & $\left(\mathrm{H}_{2} \mathrm{~S}\right)\left(\mathrm{ppm}_{\mathrm{v}}\right)$ & $\begin{array}{c}\mathbf{L R}_{\text {crit }} \\
\left(\mathrm{g} \mathrm{m}^{-3}\right. \\
\left.\mathrm{h}^{-1}\right)\end{array}$ & $\begin{array}{c}\mathrm{EC}_{\text {crit }} \\
\left(\mathrm{g} \mathrm{m}^{-3}\right. \\
\left.\mathrm{h}^{-1}\right)\end{array}$ & $\begin{array}{l}\mathrm{RE}_{\text {crit }} \\
(\%)\end{array}$ & $\begin{array}{l}\text { EBRT for } \\
\text { EC }_{\text {crit }} \\
\text { (min) }\end{array}$ & $\begin{array}{c}\mathrm{EC}_{\max } \\
\left(\mathrm{g} \mathrm{m}^{-3}\right. \\
\left.\mathrm{h}^{-1}\right)\end{array}$ & $\underset{(\%)}{\mathrm{RE}_{\max }}$ & $\begin{array}{l}\text { EBRT for } \\
\text { EC }_{\max } \\
\text { (min) }\end{array}$ & $\mathrm{pH}$ & $\mathrm{T}\left({ }^{\circ} \mathrm{C}\right)$ & $\begin{array}{l}{\left[\mathrm{NO}_{3}^{-}\right]} \\
\left(\mathrm{g} \mathrm{L}^{-1}\right)\end{array}$ & $\begin{array}{l}\text { TLF/TLV at EC } \mathrm{EC}_{\text {crit }} \\
\left(\mathrm{L} \min ^{-1 /} / \mathrm{m} \mathrm{h}^{-1}\right)\end{array}$ & $\begin{array}{c}\text { Inoculum/Packing } \\
\text { Material }\end{array}$ & $\begin{array}{l}\text { Microbial } \\
\text { Analysis }\end{array}$ & Ref. \\
\hline (18) Lab scale & $1537-2127$ & 84.4 & 84.4 & 95.7 & 1.6 & ND & ND & ND & 7 & 35 & $0.25-8$ & $0.5 / 11$ & $\begin{array}{l}\text { Community of } \\
\text { microorganisms from a } \\
\text { sample of anaerobic } \\
\text { sludge of a STP, selected } \\
\text { in the BTF/strips of PVC, } \\
\text { PET, PTFE (Teflon), OPU }\end{array}$ & $\begin{array}{c}\text { Biomass was } \\
\text { determined as } \\
\text { weight of protein } \\
\text { by weight of dry } \\
\text { support material }\end{array}$ & [30] \\
\hline
\end{tabular}

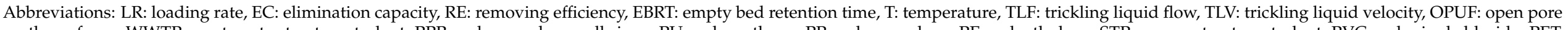

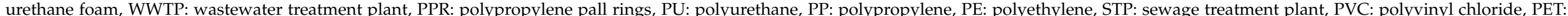
polyethylene terephthalate, PTFE: polytetrafluoroethylene, ND: not displayed or not made. 


\section{Biotrickling Filters}

As previously described, BTFs are biological devices that remove chemical contaminants from a gas flow and are considered as a type of biofilter [29,31,44]. However, there are some configuration differences between them. While in a biofilter a microorganisms culture is intermittently applied, in BTFs the culture is continuously recirculated through a packing material, forming microorganism biofilms (BFs) [16]. BFs are organized microorganism communities attached to surfaces, embedded in an exopolysaccharide (EPS) matrix, whose physiology and gene expression is different than a planktonic community. Among these differences are: (a) BF microorganisms are more resistant to environmental factors; (b) they do not limit their growth by substrate, as they can interact with the environment and among themselves since they are not fixed structures; and (c) they produce EPSs [44-46].

The basic setup of a BTF is usually a cylinder-shaped container filled with a packing material (Figure 1B) that is basically the biofilter part of the device, consisting of a sprinkler at the top (Figure 1, "shower"), from which the prokaryote microorganisms culture originated from a bioreactor or fermenter (Figure 1A) is applied. This culture drains through the packing material, contributing to the growth of prokaryote microorganism BF (usually bacteria or archaea). In the case of treating contaminated biogas, a counter current is usually applied from the lower part of the BTF (Figure 1, red arrow), ascending through the packing material containing the $\mathrm{BF}$, where the pollutants are metabolized resulting in a reduced or eliminated contaminant concentration biogas through the upper part of the device (Figure 1, green arrow). This type of solution has been tested at an industrial scale from very low concentrations to values close to $15,000 \mathrm{ppm}_{\mathrm{v}}[32,33]$.

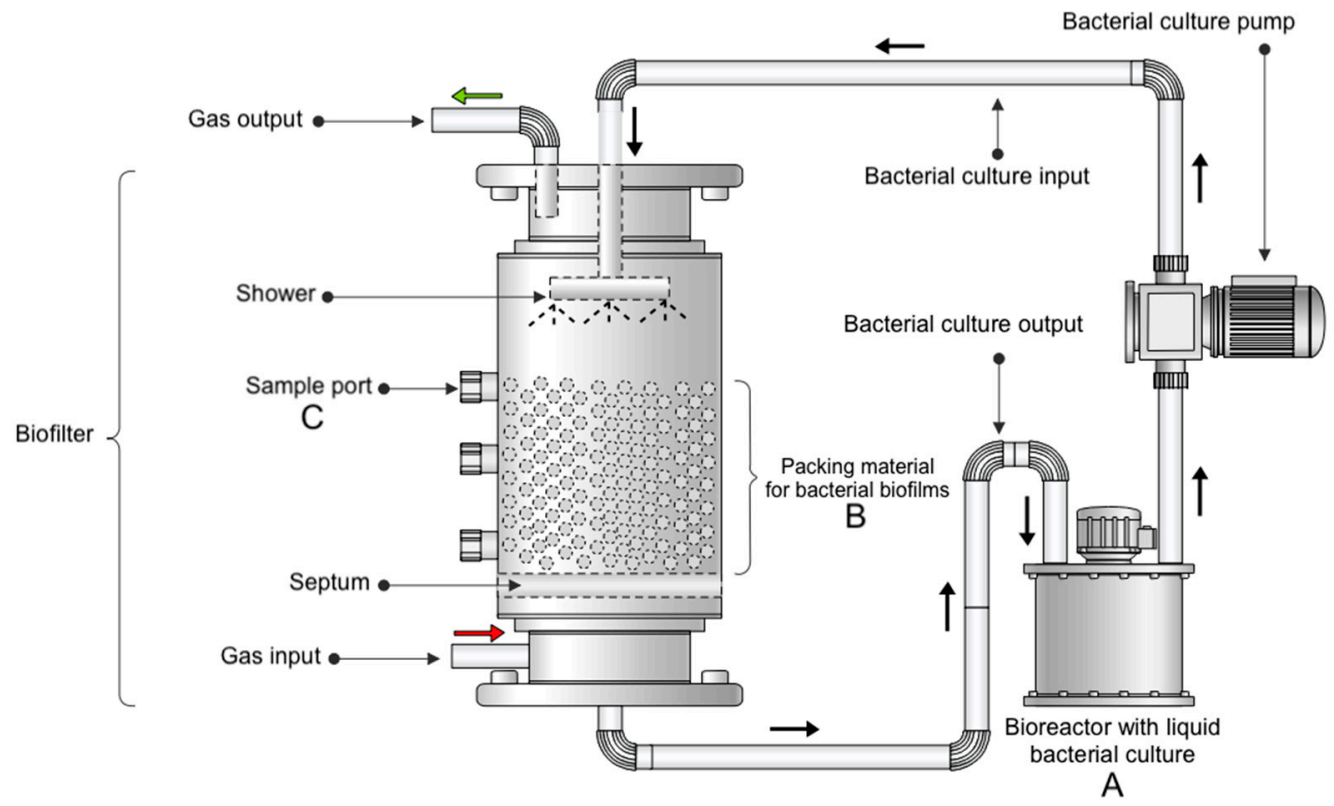

Figure 1. Basic set up of a biotrickling filter (BTF), accompanied by the bioreactor supplying bacterial culture or nutrient solution. Red arrow: $\mathrm{H}_{2} \mathrm{~S}$ contaminated biogas inlet; green arrow: BTF desulfurized biogas outlet. (A) Bioreactor or nutrient liquid container, (B) working volume, filled with packing material containing microbial biofilms and (C) port to take samples of packing material for microbiological analysis.

\section{Traditional Biofiltration Efficiency Parameters}

The main parameters that allow for the comparison of biofiltration performance are listed together with their corresponding equations in Table $3[3,19,24,39,47]$. 
Table 3. $\mathrm{H}_{2} \mathrm{~S}$ BTF efficiency parameters.

\begin{tabular}{|c|c|c|}
\hline Parameter & Equation & Variables \\
\hline $\begin{array}{l}\text { Elimination capacity of } \mathrm{H}_{2} \mathrm{~S} \\
\text { (EC) }\end{array}$ & $E C_{H_{2} S}=\left(C_{\text {in }}-C_{\text {out }}\right) \cdot \frac{Q}{V}$ & $C_{i n}=\mathrm{H}_{2} \mathrm{~S}$ input concentration \\
\hline $\begin{array}{l}\text { Removal efficiency of } \mathrm{H}_{2} \mathrm{~S} \\
\text { (RE) }\end{array}$ & $R E_{\mathrm{H}_{2} S}=\frac{\left(C_{\text {in }}-C_{\text {out }}\right)}{C_{\text {in }}}$ & $\begin{array}{l}\mathrm{C}_{\text {out }}=\mathrm{H}_{2} \mathrm{~S} \text { output } \\
\text { concentration }\end{array}$ \\
\hline $\begin{array}{l}\text { Empty bed retention time } \\
\text { (EBRT) }\end{array}$ & $E B R T=\frac{V}{Q}$ & $\begin{array}{c}V=\text { Empty bed volume of the } \\
\text { BTF bed }\end{array}$ \\
\hline $\begin{array}{l}\text { Loading rate } \\
\text { (LR) }\end{array}$ & $L R=\frac{C_{i n}}{V} \cdot Q$ & $Q=$ Biogas flow \\
\hline
\end{tabular}

Variables described in Table 3, EC versus LR and RE versus LR are usually plotted based on biofiltrations experiments as illustrated in the Figure 2 [29,30,39,44]. Theoretically, EC increases proportionally and linearly as LR increases, considering a RE of 100\% (Figure 2a). However, in all experiments documented up to date, have found a deviation of the theoretical curve (Figure $2 b$ ) from a certain critical LR (LR crit) (Figure 2c). The EC corresponding to this $\mathrm{LR}_{\text {crit }}$ is called critical EC (EC $\mathrm{ECrit}_{\text {cit }}$ ) (Figure 2d). At that point the RE (Figure 2f) is still between 99-100\% (RE for $\mathrm{EC}_{\text {crit }}$ ). The EC corresponding to the point of inflexion before its drop is called maximum EC ( $\mathrm{EC}_{\max }$ ) (Figure 2g), which reflects an RE lower than $99 \%$ (Figure 2i) [24]. It is desirable for a BTF to have an experimental curve that is as close to the theoretical curve as possible and that the $\mathrm{EC}_{\text {crit }}$ should have the highest possible value [39]. Similarly, the RE has a theoretical curve of $100 \%$ removal (Figure 2e), but actually, the curve deviates towards lower removal percentages (Figure $2 \mathrm{f}$ ), usually close to $90 \% \mathrm{RE}$ (Figure $2 \mathrm{i}$ ), when the EC value approaches $\mathrm{EC}_{\max }$ (Figure $2 \mathrm{~g}$ ) and the maximum LR (LR $\max$ ) (Figure 2h) [47-50].

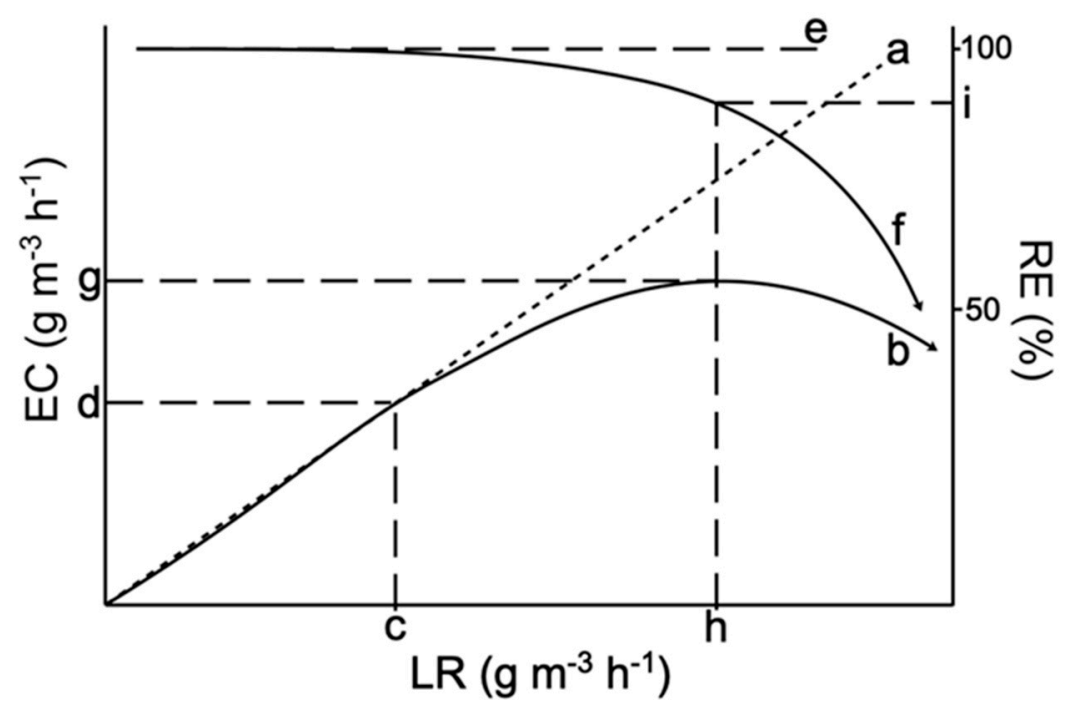

Figure 2. Typical elimination capacity (EC) versus loading rate (LR) and removal efficiency (RE) versus LR graphs. (a) Theoretical EC curve, (b) experimental EC curve, (c) critical LR, (d) critical EC, (e) theoretical RE curve, and (f) experimental RE curve, (g) maximum EC, (h) maximum LR and (i) RE for the maximum EC.

On the other hand, $\mathrm{H}_{2} \mathrm{~S}$ contaminated biogas must remain in the BTF bed for a certain amount of time so that it comes into contact with the sulphur oxidizing bacteria (SOB) biofilms in order for the $\mathrm{H}_{2} \mathrm{~S}$ biological oxidation to occur. Such as interval is called the empty bed residence time (EBRT) (Table 3). Thus, a graph of RE versus EBRT is drawn (Figure 3) where RE increases along with EBRT (Figure 3a) while LR decreases (Figure 3b) [39]. The EBRT value can range from a few seconds to hours $[41,51]$. The higher the value, the higher the 
RE, although, the LR will be lower and lower. Furthermore, at very high EBRT values, high volume BTFs are needed [3]. Thus, a BTF will be more efficient at an optimal LR, allowing the highest EC, RE, and EBRT at the same time.

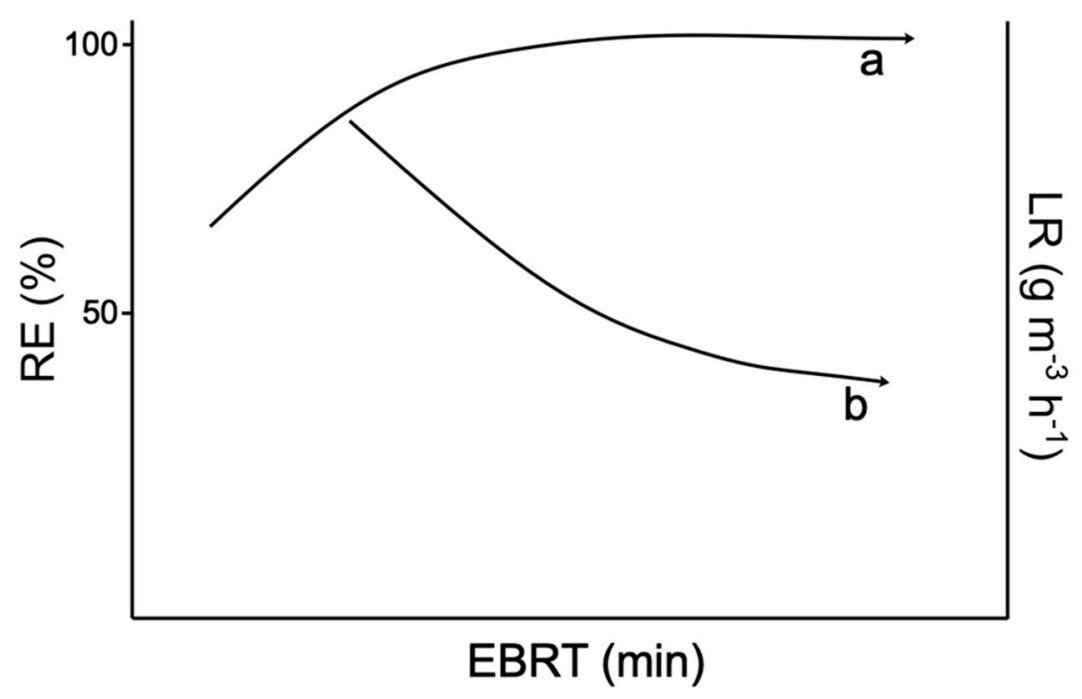

Figure 3. Typical RE versus EBRT and LR versus EBRT graphs. (a) RE and (b) experimental LR.

The determination of critical and maximum markers is already an accepted methodology to compare BTF performances [24]. However, research reporting only maximum or only critical values are still published (Table 2).

\section{BTF Microbiological Study}

Sulphur is one of the most abundant elements on our planet, being found in the lithosphere, hydrosphere, and atmosphere in the form of chemical species such as sulphates $\left(\mathrm{SO}_{4}{ }^{2-}\right)$, mineral sulphides (pyrite, $\left.\mathrm{FeS}_{2}\right)$, elemental sulphur (S0), and the totally reduced sulphur compounds (TRS), such as hydrogen sulphide $\left(\mathrm{H}_{2} \mathrm{~S}\right)$, dimethylsulphide (DMS), dimethyl disulphide (DMDS), and methyl mercaptane (MM) [51,52]. The transformation from one chemical species to another is carried out by the sulphur cycle in which the most reduced ion is $\mathrm{S}^{2-}$, and the most oxidized is $\mathrm{SO}_{4}{ }^{2-}$. The latter is reduced by plants, fungi, archaea, and bacteria to form amino acid-sulphur compounds that become protein parts through the assimilation pathway [3]. However, there are sulphate-reducing bacteria that carry out non-assimilative metabolic pathways, releasing TRS in a gaseous form. In AD, one of the main TRS is $\mathrm{H}_{2} \mathrm{~S}$, which within the sulphur cycle is oxidized by SOB $[3,53]$. SOB are a diverse group of bacteria and archaea, which use TRS and other not totally reduced sulphur compounds (such as thiosulphate, $\mathrm{S}_{2} \mathrm{O}_{3}{ }^{2-}$ ) as electron donors (energy source); oxygen as the ultimate electron acceptor in the case of aerobic SOB; and the $\mathrm{NO}^{3-}$ as the last electron acceptor in the case of anaerobic SOB $[18,54]$. The latter, known as chemolithotrophic denitrifying SOB, display an advantage due to the fact that BTF or bioreactor aeration cycles are not necessary. In this bacterial group, $\mathrm{NO}_{3}{ }^{-}$denitrification can be completely carried out up to $\mathrm{N}_{2}$ or incompletely up to $\mathrm{NO}_{2}{ }^{-}[55,56]$. Thus, when $\mathrm{N} / \mathrm{S}>1.6$ is given, anoxic $\mathrm{SOB}$ oxidize the $\mathrm{H}_{2} \mathrm{~S}$ and reduce the $\mathrm{NO}_{3}{ }^{-}$completely down to $\mathrm{SO}_{4}{ }^{2-}$ and $\mathrm{N}_{2}$, respectively, while at $\mathrm{N} / \mathrm{S}<0.4$ such bacteria only perform oxidoreduction down to $\mathrm{S}^{0}$ and $\mathrm{NO}_{2}{ }^{-}[18,55]$. Added to the actual behaviour of the EC and the RE with respect to the LR, this strongly suggests that BTFs should be microbiologically studied to maintain a strain or bacterial community that is efficient in terms of the parameters described above. This study should not only be carried out in terms of identifying the microorganisms involved and their proportion (through molecular techniques), but it should also quantify the biomass that adheres to the support material in order to evaluate 
the efficiency of the bacterial groups involved. This also leads to another very important point: the evaluation of different packing materials.

\subsection{SOB Molecular Characterization in an Anoxic Desulphurisation BTF}

Due to the above, SOB have become the focus of much research on TRS bioremediation, with chemolithotrophic species (which use $\mathrm{CO}_{2}$ as their sole carbon source) being more attractive as they are economically easier to maintain, as there is no need to add an organic carbon source to the culture medium. Among the research mentioned (Table 2) are those describing biogas anoxic desulphurisation (Table 2), in which parameters of BTF efficiency have been widely described, but their microbiological study is scarce [18]. Anoxic $\mathrm{H}_{2} \mathrm{~S}$ biofiltration studies are very recent and most refer to the analysis of the gene encoding 16S rRNA from samples of packing material taken at different heights of the BTF $[32,35,42,44]$. However, there are two types of samples to be considered in the study of microbiological changes occurring in a BTF: (1) the support material that is inside the BTF bed, where the bacterial biofilms to be used in the bioremediation are formed, as previously described (Figure 1B); and (2) the bacterial culture contained in the bioreactor of the BTF, the analysis of which we also propose, since it influences changes in the BTF (Figure 1A). Regarding this last point, there are disadvantages in laboratory-scale experimentation as when taking samples from the support material it is necessary to open the sample ports (Figure 1C) interrupting the anaerobiosis affecting the BTF's performance and requiring a re-acclimatization that must be standardized for each experiment, according to the $\mathrm{AD}$ biogas composition. Most of the studies described (Table 2) have analysed changes in the BTF microbial community through the DNA extraction from the bacterial resuspension obtained from the packing material, the subsequent amplification of the gene encoding $16 \mathrm{~S}$ rRNA, and later analysis by denaturing gradient gel electrophoresis (DGGE) $[32,42,44]$ or by amplifying sequences and making phylogenetic analysis [35].

\subsubsection{Denaturing Gradient Gel Electrophoresis (DGGE)}

Denaturing gradient gel electrophoresis (DGGE) is a genetic analysis based on a polymerase chain reaction (PCR), in which amplified DNA fragments are separated into a polyacrylamide gel with a denaturing gradient of different formamide proportions $[57,58]$. This technique was developed in the 1970s [59] and was credited with the potential to detect almost the 100\% of the differences in a DNA sequence. In the 1990s, DGGE began to be used for the analysis of complex bacterial communities through the separation of amplifiers of the gene encoding $16 \mathrm{~S}$ rRNA, considered to be an evolutionary chronometer in bacteria [57,60]. Previous stages and the DGGE analysis are illustrated in Figure 4. As a result of the DGGE, the gel capture is presented (Figure 5), which generally includes lanes containing the amplified $16 \mathrm{~S}$ rDNA of the inoculated strain (Figure 5, lane A), sample from the bioreactor (Figure 5, lane B), and samples of support material with biofilms from different sections of the BTF (Figure 5 lanes C, D, and E). Through the analysis of the band pattern in different cases of anoxic biofiltration for $\mathrm{H}_{2} \mathrm{~S}$ removal as described above, the influence of various operational parameters on changes in the packing material, the EBRT, the $\mathrm{Q}$, and the $\mathrm{NO}_{3}{ }^{-}$concentration, among others, associating them with the RE to explain the BTF behaviours that, frequently, are not supported by the analysis of the traditional efficiency indicators mentioned in point $3[32,42,44]$. 


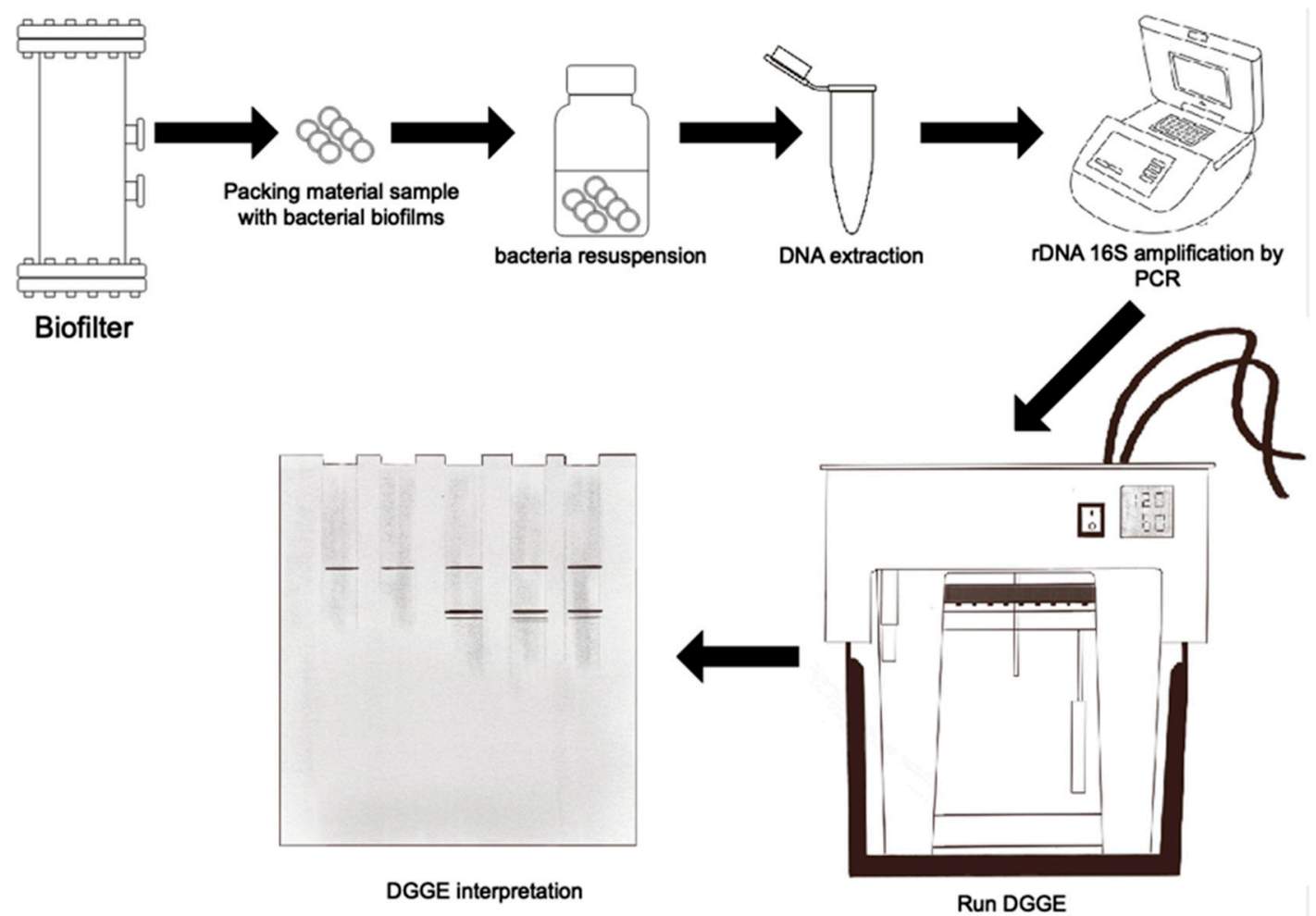

Figure 4. Steps to be followed in the DGGE protocol.

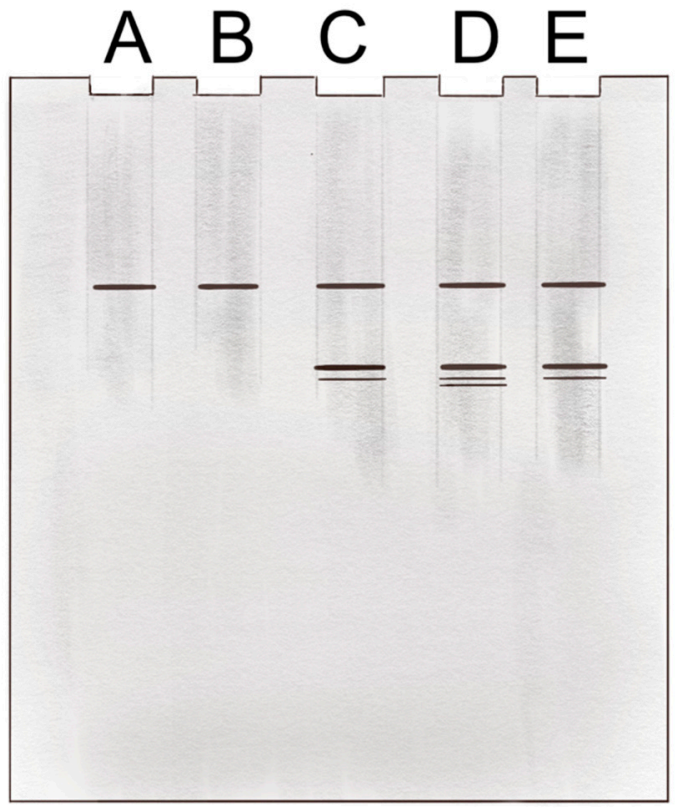

Figure 5. Typical denaturing gradient gel in microbiota analysis in a BTF. Lanes: (A) pure inoculated strain, (B) bioreactor sample, (C) basal section of the BTF sample, (D) middle section of the BTF sample, and (E) upper section of the BTF sample.

\subsubsection{DGGE Protocol}

The protocol to conduct a BTF bacterial community analysis through DGGE, prior to the PCR of the gel, has been widely described and is illustrated in Figure $4[43,61]$. 


\subsubsection{DGGE Interpretation}

DGGE interpretation is done in two non-exclusive manners: (1) comparison of the bacterial biodiversity of the BTF at different stages; (2) DNA sequencing of the fragments obtained in the DGGE.

In the first case, the DGGE is considered as a BTF snapshot at a determined stage. Performing the DGGE under different operational conditions allows the comparison of the band pattern obtained each time. The more bands obtained, the greater the diversity. Based on these DGGE profiles and as a diversity index, the range-weighted richness ( $R r)$ is calculated for each lane, as described below:

$$
\mathrm{Rr}=\mathrm{N} 2 \times \mathrm{D}
$$

where $\mathrm{N}$ is the number of bands contained in the sample (one DGGE lane) and $\mathrm{D}$ is the denaturing percentage range in which these bands are found. It is considered low richness (low diversity) when $\mathrm{Rr}<10$, mean when $10<\mathrm{Rr}<30$, and high when $\mathrm{Rr}>30$ [62]. This analysis is appropriate when the BTF has been inoculated with a known bacterial community or strain, so that each of the DGGE lanes and their $\mathrm{Rr}$ will indicate if the community or strain changes according to operational changes in the BTF. It is conventional to qualitatively report the similarity between the strain or community control band patterns (initial inoculum) and the samples taken at different stages of the BTF (e.g., temperature disturbances, $\mathrm{pH}$ disturbances, change of culture medium, nutrient concentration, among others).

In the second case, DGGE is used as a method for isolating amplified DNA, separating fragments with differences of one base pair. The bands are cutted, their DNA is resuspended and amplified again, and then they are sequenced. These sequences are used to perform a taxonomic search as described in chapter 16 of the NCBI Handbook [63] and in web BLAST page options [64]. Then, a detailed phylogenetic analysis is made for each BTF stage and thus, it is investigated if the inoculated taxonomic groups are maintained, if others have appeared, or if some have been eliminated [43]. This analysis is convenient when the BTF has been inoculated with a bacterial community or with residues in which the intention is to select, in the BTF, the most efficient microorganisms and taxonomically identify them. Frequently, a table identifying taxonomically the sequences corresponding to each band is reported [43].

\subsubsection{DNA Pyrosequencing}

The microbial diversity dynamics are also investigated through DNA sequencing techniques of the entire BTF biomass sample, such as tag-encoded FLX-amplicon pyrosequencing (TEFAP) in a FLX 454 instrument (Roche, USA). This technique was the first of the so-called next-generation sequencing, implemented in 2005 [65]. This technique allows parallel sequencing of many different fragments at the same time and is ideal for obtaining DNA sequences of all the microorganisms in a biomass sample from a BTF, without the need for a previous separation in a gel or the requirement to isolate the strains [35].

\subsubsection{TEFAP Protocol}

The procedure for analyzing the BTF bacterial community through TEFAP is illustrated in Figure 6, as described in the literature [31].

\subsubsection{TEFAP Interpretation}

In this case the DNA data analysis consists of the taxonomic search of the sequences obtained in a database, as described for the second case of DGGE in point 4.1.3 and representing all the different $16 \mathrm{~S}$ rDNA sequences found in the sample. Thus, this analysis is convenient when the BTF has been inoculated with an unknown bacterial community or with residues, which are to be taxonomically selected and identified. As mentioned in point 4.1.3, usually a table identifying taxonomically each sequence is reported. In other cases, a phylogenetic tree, often of the neighbour-joining type whose evolutionary distances are 
computed using the maximum composite likelihood method, has been used to report this data $[58,66,67]$.

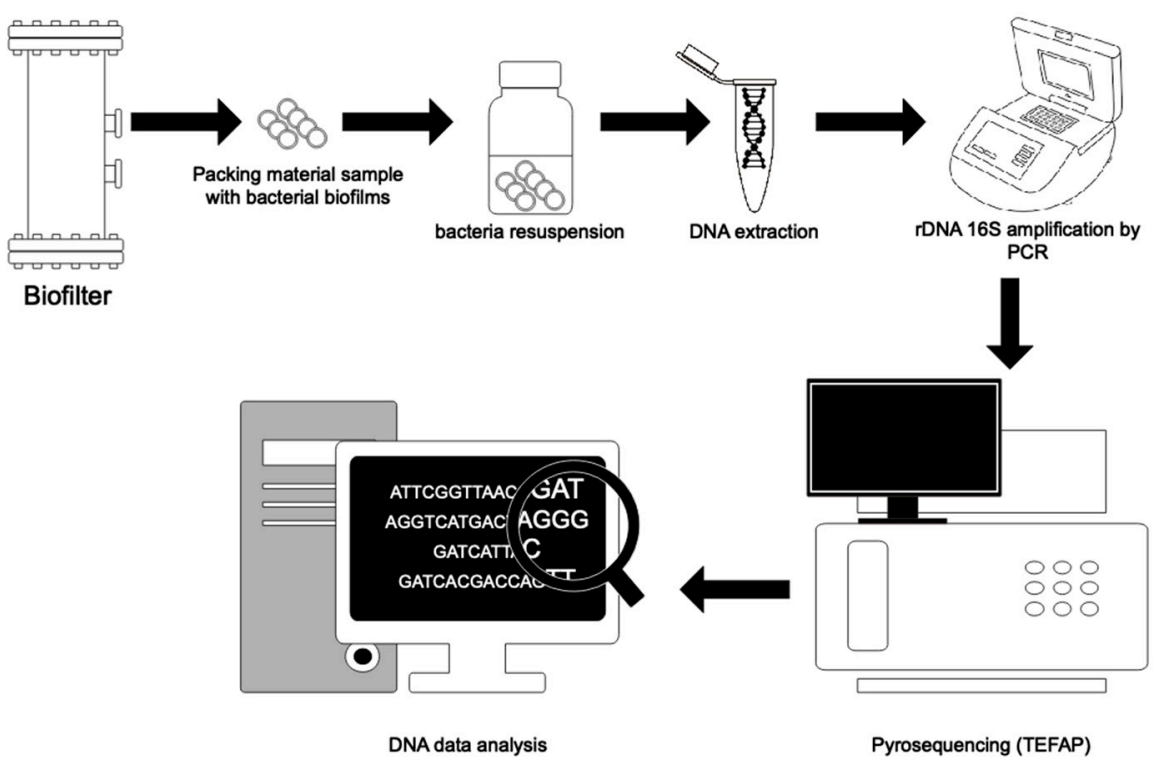

Figure 6. Tag-encoded FLX-amplicon pyrosequencing (TEFAP) procedure.

\subsection{Determination of the Biomass Attached to the Support Material (Biofilms)}

The methods for quantitative and qualitative biomass determination used in anoxic BTFs (found in the cited research, Table 2) for biogas desulphurisation are summarized in Table 4. Usually, a quantitative microscopic, plate culture, or genetic method that delivers a cell value, CFU, or gene copy number (DNA sequence) is selected, which is expressed per dry weight unit or per unit area of the packing material.

Table 4. Common biofilm quantification methods in BTFs research.

\begin{tabular}{|c|c|c|c|c|}
\hline Method & Technique & Advantage & Disadvantage & Ref. \\
\hline $\begin{array}{c}\text { Microorganisms cell } \\
\text { count by weight or area } \\
\text { of dry packing material } \\
\text { (quantitative). }\end{array}$ & $\begin{array}{l}\text { Direct count of cells in a } \\
\text { Neubauer chamber } \\
\text { through optical } \\
\text { microscopy. }\end{array}$ & $\begin{array}{c}\text { Fast, easy, } \\
\text { and inexpensive. }\end{array}$ & $\begin{array}{l}\text { No information about the } \\
\text { viable cells. It cannot } \\
\text { made if the cells are } \\
\text { too little. }\end{array}$ & {$[26,34]$} \\
\hline $\begin{array}{l}\text { Colony forming units } \\
\text { (CFU) count by weight or } \\
\text { area of dry packing } \\
\text { material (quantitative). }\end{array}$ & $\begin{array}{l}\text { Biofilm resuspension } \\
\text { spreading in agar plate } \\
\text { dishes and anoxic } \\
\text { incubation for } 14 \mathrm{~d} .\end{array}$ & $\begin{array}{l}\text { Easy and relatively } \\
\text { inexpensive. Reports the } \\
\text { viable biomass. }\end{array}$ & $\begin{array}{l}\text { Long period of time to } \\
\text { obtain results }(\sim 14 \mathrm{~d}) \text {. }\end{array}$ & [39] \\
\hline $\begin{array}{l}\text { DNA sequences copies } \\
\text { (quantitative). }\end{array}$ & $\begin{array}{c}\text { rDNA 16S } \\
\text { pyrosequencing (TEFAP). }\end{array}$ & $\begin{array}{c}\text { Reports the } \\
\text { microorganisms identity } \\
\text { and their } \\
\text { relative abundance. }\end{array}$ & $\begin{array}{l}\text { No information about the } \\
\text { viable cells. }\end{array}$ & [35] \\
\hline $\begin{array}{l}\text { Relative intensity of a } \\
\text { DNA amplification } \\
\text { product (quantitative). }\end{array}$ & $\begin{array}{l}\text { rDNA 16S PCR, DGGE, } \\
\text { and calculation of the } \\
\text { relative abundance by } \\
\text { band intensity. }\end{array}$ & $\begin{array}{l}\text { Relative abundance by } \\
\text { taxa previously selected as } \\
\text { control microorganisms. } \\
\text { An easy way to measure } \\
\text { microbial } \\
\text { community changes. }\end{array}$ & $\begin{array}{l}\text { It is restricted to the } \\
\text { previous selection of } \\
\text { control cultures (e.g., } \\
\text { ATCC, DSM) and } \\
\text { specific primers. }\end{array}$ & {$[25,42]$} \\
\hline
\end{tabular}


Table 4. Cont.

\begin{tabular}{|c|c|c|c|c|}
\hline Method & Technique & Advantage & Disadvantage & Ref. \\
\hline $\begin{array}{c}\text { Gene copies by cDNA } \\
\text { sample (mRNA copies) } \\
\text { (quantitative). }\end{array}$ & RT-qPCR. & $\begin{array}{l}\text { Relatively fast and easy. It } \\
\text { reports the number of } \\
\text { mRNA in the sample, } \\
\text { proportional to the } \\
\text { number of viable bacteria } \\
\text { in the specific taxonomic } \\
\text { group previously selected. }\end{array}$ & $\begin{array}{l}\text { It is restricted to the } \\
\text { previous selection of } \\
\text { specific primers and it } \\
\text { needs cloning to make the } \\
\text { calibration curve. }\end{array}$ & [38] \\
\hline $\begin{array}{l}\text { Protein weight by weight } \\
\text { or area of dry packing } \\
\text { material (quantitative). }\end{array}$ & $\begin{array}{l}\text { Quantification of total } \\
\text { proteins by Lowry } \\
\text { technique }\end{array}$ & $\begin{array}{l}\text { Relatively inexpensive, } \\
\text { fast, and easy. Total } \\
\text { proteins are proportional } \\
\text { to viable biomass. }\end{array}$ & $\begin{array}{l}\text { Restricted to the detection } \\
\text { limits of the protein } \\
\text { determination kit or the } \\
\text { preparation of reactants. }\end{array}$ & [30] \\
\hline $\begin{array}{l}\text { Observation of the } \\
\text { microorganisms on the } \\
\text { surface of packing } \\
\text { material (qualitative). }\end{array}$ & $\begin{array}{l}\text { Scanning electron } \\
\text { microscopy (SEM). }\end{array}$ & $\begin{array}{l}\text { Reports the cells } \\
\text { morphology, size, and the } \\
\text { formation of EPS } \\
\text { filaments and fimbriae. It } \\
\text { shows the topology of the } \\
\text { biofilm. Coupled to } \\
\text { material analysis, it } \\
\text { reports the chemical } \\
\text { elements that surrounds } \\
\text { the biofilm cells. }\end{array}$ & $\begin{array}{l}\text { No information about the } \\
\text { viable cells. A relative } \\
\text { quantification is only } \\
\text { possible when the biofilm } \\
\text { has a single layer of cells. }\end{array}$ & {$[32,37]$} \\
\hline
\end{tabular}

Other BTF Biofilm Quantification Methods Proposed

Other BTF biofilm quantification methods provide important data to explain behaviour differences between them, but they have not been used in anoxic BTFs for biogas desulphurisation, are described in Table 5.

Table 5. Methods of viable microorganism quantification in BTFs.

\begin{tabular}{|c|c|c|c|c|}
\hline Method & Technic & Advantage & Disadvantage & Ref. \\
\hline $\begin{array}{l}\text { Microorganisms cells } \\
\text { count by weight or area of } \\
\text { dry packing material } \\
\text { (quantitative and } \\
\text { qualitative). }\end{array}$ & $\begin{array}{l}\text { Direct count of cells by } \\
\text { optical epifluorescence } \\
\text { microscopy with } \\
\text { live-death stain (Baclight, } \\
\text { Thermofischer, Waltham, } \\
\text { MA, USA). }\end{array}$ & $\begin{array}{l}\text { Relatively fast and easy. } \\
\text { Reports the viable and } \\
\text { not viable cells. If } \\
\text { observed in a confocal } \\
\text { laser scanning } \\
\text { microscope (CSLM), } \\
\text { biofilm topology and } \\
\text { thickness is reported. }\end{array}$ & $\begin{array}{c}\text { Relatively expensive and } \\
\text { low capacity of sample } \\
\text { processing quantity. }\end{array}$ & {$[68,69]$} \\
\hline $\begin{array}{l}\text { Colony forming units } \\
\text { (CFU) count by weight or } \\
\text { area of dry packing } \\
\text { material (quantitative). }\end{array}$ & $\begin{array}{l}\text { Drops of serial dilutions } \\
\text { of biofilm resuspension } \\
\text { spreading in agar plate } \\
\text { dishes or } 24 \text {-well agar } \\
\text { microplates and anoxic } \\
\text { incubation for } 14 \mathrm{~d} \text {. }\end{array}$ & $\begin{array}{l}\text { Cost-effective and allows } \\
\text { many replicates } \\
\text { producing better } \\
\text { statistical data. Reports } \\
\text { the viable CFU. }\end{array}$ & $\begin{array}{l}\text { Long period of time to } \\
\text { obtain results }(\sim 14 \mathrm{~d}) \text {. }\end{array}$ & {$[47,70,71]$} \\
\hline
\end{tabular}

\section{Anoxic BTF Packing Materials for Biogas Desulphurisation}

The selection of the appropriate packing material is vital for a BTF and has been the subject study of numerous research works, since it influences the contaminants degradation kinetics, affecting the EC of a BTF as per the nature of the material and its size [18,72]. There is a large number of packing materials described for obtaining biofilms used in BTF. The most common ones are organic materials such as peat, soil, and compost, followed by wood bark, sugarcane bagasse [73], and peanut shells [74]. However, these materials when compressed are easily clogged with bacterial biomass or an accumulation of elemental sul- 
phur, causing pressure drops and eventually decreasing the performance of the BTF $[18,27]$. Inorganic materials such as glass spheres and perlite have been demonstrated to provide improved mechanical and hydrodynamic properties, producing constant biogas pressure in the BTF over time $[18,75,76]$. Although of an elevated cost, metal oxides such as porous ceramics, volcanic rocks [77], and perlite [50] are most commonly used. Combinations of organic and inorganic materials have also been studied, pursuing the addition of the nutritional properties of the organic materials and the mechanical properties of the inorganic compounds [76]. Polymeric materials such as polyethylene [39], polypropylene [23], plastic rings, and polyurethane foam [18] have also been used, offering advantages such as a high specific area and characteristics of hydrophobic afiinity with the attached microorganisms. Other materials, such as volcanic rock, have stood out for their porosity, facilitating the settlement of the SOB to be used [18].

The most important properties of a packing material are large surface area, high porosity, high chemical stability (one that will not be degraded by the treated chemicals or by-products), structural firmness (so as not to produce small pore sizes and thus prevent plugging), low cost, and high affinity with biofilm-forming bacteria [72].

Studies including the evaluation of different packing materials for the attachment of SOB biofilm for anoxic biogas desulphurisation are very scarce and are limited to four works described in Table $2[25,27,33,40]$. Among them, research by Ben Jaber et al. [40] and Tayar et al. [30] stand out. The first work investigated expanded schist and cellular concrete inoculated with activated sludge from a wastewater treatment plant, where it was found that expanded schist was the best support material through the comparison of the EC produced by each of them (30.3 $\mathrm{g} \mathrm{m}^{-3} \mathrm{~h}^{-1}$ for expanded schist and $25.2 \mathrm{~g} \mathrm{~m}^{-3} \mathrm{~h}^{-1}$ for cellular concrete), though no microbiological studies, such as the measurement of the biomass by surface area of packing material or the evaluation of the microbial population composition, were carried out in this regard. In the second work, different cost-effective polymeric materials were tested: strips of PVC, polyethylene terephthalate (PET), polytetrafluoroethylene (Teflon), and OPUF. The findings of this work suggested that the best cost-effective polymeric material in anoxic BTF for biogas desulphurisation is PVC, based on the comparison of operational parameters such as temperature and $\mathrm{H}_{2} \mathrm{~S} \mathrm{LR}$. As for microbiological study, the determination of microorganism biomass through the quantification of the total protein mass per dry packing material mass was included. The biomass immobilized in the PVC was 1.7 times less than that in the OPUF (15 and 25.4 mass of protein per mass of dry support $\left(\mathrm{mg} \mathrm{g}^{-1}\right)$ ), but the $\mathrm{EC}_{\text {crit }}$ produced in the BTF packed with PVC $\left(84.4 \mathrm{gS} \mathrm{H}_{2} \mathrm{~S} \mathrm{~m}^{-3} \mathrm{~h}^{-1}\right)$ was six times higher than the BTF with OPUF $\left(14 \mathrm{gS} \mathrm{H}_{2} \mathrm{~S} \mathrm{~m}^{-3} \mathrm{~h}^{-1}\right)$. This experiment demonstrated that PVC is a better packing material because the performance produced is higher, the biomass accumulation is less which helps to prevent the BTF clogging, and it is cheaper (USD \$0.21 for PVC and USD $\$ 0.67$ for OPUF in BTFs with $3 \mathrm{~L}$ of working volume).

The lack of microbiological studies on the evaluation of BTF packing materials is important, since a material related to a prokaryotic microorganism taxonomic group will not necessarily be related to all the taxa and mixtures found in the BTF inoculum. Thus, as shown in Table 2, the inoculums used in investigations are diverse and, therefore, so are the microorganism taxonomic groups used. However, most of the BTF research groups are inclined to use polymeric materials, among which polyethylene or polypropylene rings (Pall rings and K1 Kaldness rings, among others) stand out. It has been inferred that this is due to the hydrophobic characteristics of such materials. However, thorough studies, including microbiological parameters such as microbial identity, and CFU or viable cells count per unit area in the packing material, are necessary. Thus, specific growth speed $(\mu)$ will be a factor to consider in calculating how efficient is a prokaryote with a given packing material $\left(\mathrm{g} \mathrm{H}_{2} \mathrm{~S} \mathrm{~d}^{-1}\right.$ cell $\left.^{-1}\right)$ [52].

\section{Discussion}

Traditional and microbiological markers are useful to compare the performance of BTFs (and biofilters) in terms of their removal of $\mathrm{H}_{2} \mathrm{~S}$ from biogas, and the need to si- 
multaneously report and relate them are described and discussed in this review [16,24]. In this regard, all publications on this topic from 2010 to 2020 describing traditional and microbiological markers for anoxic biogas desulphurisation BTFs were reviwed and it was found that there was no uniformity in the presentation of parameters: sometimes only traditional critical markers were reported, and in other cases only the maximum ones (EC, LR, RE, and EBRT), neglecting important analyses in several cases. Thus, it was found that $56 \%$ of the publications reviewed did not report any microbiological analysis related to SOB (Table 2: 2, 4, 5, 7, 8, 9, 10, 12, 13, and 15). On the other hand, it was found that $78 \%$ of the research presented in this review was undertaken at a laboratory scale, $17 \%$ at a pilot scale, and only one research at the field scale, demonstrating that the pilot and full scales still present a challenge, an opinion shared by other reviews [78]. This exposes fundamental shortcomings in this type of research and there are several reasons why it is difficult to compare performances between research works in order to guide the reader in terms of progress made in this field: (a) the research described in this review does not always report the critical and maximum values of the traditional markers (Table 2), which has been established as essential in recent specialized literature in the field of biofiltration [24]; (b) there is a lack of microbiological analysis to better understand which bacterial populations are more efficient in BTFs for biogas treatment, we agree with other researchers in this regard [18,79]; and (c) there is still much research to be published on the use of BTFs for desulphurisation on an industrial scale, an opinion shared between scientists in the field [79]. This is mainly due to the difficulties of achieving a robust and reliable operation of the BTFs [21]. For this reason, we propose a framework of minimum parameters to be considered to compare the performance of anoxic BTFs for biogas desulphurisation (Table 6) and thus evaluate research in this field in a complete and uniform way. These parameters can be applied to BTFs for any type of gas treatment.

Table 6. Suggested set of traditional and microbiological parameters that every research on BTFs should include.

\begin{tabular}{|c|c|}
\hline Parameter & Description \\
\hline \multicolumn{2}{|c|}{ Traditional Markers of Efficiency in BTFs for Biogas Desulphurisation } \\
\hline $\mathrm{EC}_{\text {crit }}\left(\mathrm{g} \mathrm{m}^{-3} \mathrm{~h}^{-1}\right)$ & Elimination capacity at $90-100 \%$ of RE. \\
\hline $\operatorname{LR}_{\text {crit }}\left(\mathrm{g} \mathrm{m}^{-3} \mathrm{~h}^{-1}\right)$ & $\begin{array}{l}\text { Loading rate of pollutant at } 90-100 \% \text { of } \mathrm{RE} \text {, theoretically its value is } \\
\text { equal to } \mathrm{EC}_{\text {crit }} \text {. }\end{array}$ \\
\hline EBRT for $\mathrm{EC}_{\text {crit }}(\mathrm{min})$ & $\begin{array}{l}\text { Empty bed retention time at the } \mathrm{EC}_{\text {crit }} \text {, sometimes is equivalent to } \\
\text { EBRT for } \mathrm{EC}_{\max } \text {. }\end{array}$ \\
\hline $\mathrm{EC}_{\max }$ & $\begin{array}{l}\text { Maximum elimination capacity }(\mathrm{EC}) \text {. Corresponds to the inflexion } \\
\text { point or the first value of the asymptotic part of the EC versus LR } \\
\text { curve. }\end{array}$ \\
\hline $\mathrm{LR}_{\max }\left(\mathrm{g} \mathrm{m}^{-3} \mathrm{~h}^{-1}\right)$ & Loading rate (LR) at the $\mathrm{EC}_{\max }$. \\
\hline $\mathrm{RE}$ for $\mathrm{EC}_{\max }$ & Removing efficiency at $\mathrm{EC}_{\max }$. \\
\hline EBRT for $\mathrm{EC}_{\max }$ & $\begin{array}{l}\text { Empty bed retention time at the } \mathrm{EC}_{\max } \text {, sometimes equivalent to } \\
\text { the EBRT for } \mathrm{EC}_{\text {crit. }}\end{array}$ \\
\hline
\end{tabular}


Table 6. Cont

\begin{tabular}{|c|c|}
\hline Parameter & Description \\
\hline \multicolumn{2}{|r|}{ Microbiological markers } \\
\hline Inoculum description & Detail of the sample, culture, or strain for the inoculum. \\
\hline Quantification of biomass & $\begin{array}{l}\text { Bacterial cell count by packing material surface, through } \\
\text { microscopic cell counting in Neubauer chamber or Baclight stain. } \\
\text { CFU by packing material surface, through the drop plate method. }\end{array}$ \\
\hline $\begin{array}{l}\text { Initial microbial ecology } \\
\quad \text { (after start-up) }\end{array}$ & $\begin{array}{l}\text { DGGE or TEFAP for the biofilm in the packing material of the BTF } \\
\text { and the liquid culture in the bioreactor. }\end{array}$ \\
\hline $\begin{array}{l}\text { Final microbial ecology } \\
\text { (at } \mathrm{EC}_{\mathrm{crit}} \text { and } \mathrm{EC}_{\max } \text { times) }\end{array}$ & $\begin{array}{l}\text { DGGE or TEFAP for the biofilm in the packing material of the BTF } \\
\text { and the liquid culture in the bioreactor. }\end{array}$ \\
\hline $\begin{array}{l}\text { Microbial ecology under } \\
\text { perturbation }\end{array}$ & $\begin{array}{c}\text { DGGE or TEFAP for the biofilm in the packing material of the BTF } \\
\text { and the liquid culture in the bioreactor. }\end{array}$ \\
\hline
\end{tabular}

On other hand, in silico experiments utilizing mathematical modelling have gained attention in recent years, simulating the behaviour of real bioreactors to enable the better understanding of their processes and allowing the selecting of appropriate operational parameters for real solutions [80]. In this regard, a recent work of López et al. (2021) evaluated the effect of different control strategies in an aerobic BTFs for biogas desulfurisation under different $\mathrm{H}_{2} \mathrm{~S}$ LR conditions [21]. This research group found that the control of the trickling liquid velocity is one of the bests strategies for the regulation of the performance of the BTF at a $\mathrm{H}_{2} \mathrm{~S}$ LR below $169 \mathrm{~g} \mathrm{~m}^{-3} \mathrm{~h}^{-1}$ when perturbations in the inlet $\mathrm{H}_{2} \mathrm{~S}$ concentration occur, being applicable to the research described in Table 2, in which the LR used was under $130 \mathrm{~g} \mathrm{~m}^{-3} \mathrm{~h}^{-1}$ in the most of cases. Although this research is focused on aerobic BTFs, similar modelling results were described by Almenglo et al. in 2015 for anoxic BTFs, in which a higher feeding of $\mathrm{NO}_{3}{ }^{-}$in the trickling solution (1380 $\mathrm{g}$ over $920 \mathrm{~g}$ ) allowed the outlet $\mathrm{H}_{2} \mathrm{~S}$ to be kept between 1.46-1.47 g, in sight of $\mathrm{H}_{2} \mathrm{~S}$ LR variations of $149.4 \mathrm{~g} \mathrm{~m}^{-3} \mathrm{~h}^{-1}$ over $94.1 \mathrm{~g} \mathrm{~m}^{-3} \mathrm{~h}^{-1}$ [81]. This type of mathematical model development, including the traditional performance parameters (Table 6), are a powerful tool to evaluate operational strategies, added to the microbiological markers suggested in the Table 6.

\section{Conclusions}

This review suggests that the performance of BTFs should be assessed through a set of traditional and microbiological parameters described in the Table 6, because BTFs are biological systems and not merely chemical systems subjected to scrutiny. We consider that, at least, studies undertaken at the laboratory scale will be more revealing in terms of knowledge generation and application, if they are carried out this way. Additionally, more pilot and industrial scale studies are necessary and will be very useful for the comparison of biofiltration devices, if the complete spectrum of performance and microbiological markers are tested.

Author Contributions: Conceptualization, E.V.-R. and F.H.; methodology, E.V.-R.; software, E.V.-R.; validation, R.D., F.M., D.G. and F.H.; formal analysis, E.V.-R. and R.D.; investigation, E.V.-R. and F.H.; resources, F.H.; data curation, E.V.-R. and F.H.; writing—original draft preparation, E.V.-R.; writing-review and editing, R.D.; visualization, R.D. and E.V.-R.; supervision, E.V.-R. and F.H.; project administration, E.V.-R.; funding acquisition, F.H. All authors have read and agreed to the published version of the manuscript.

Funding: This review was funded by Procycla SpA/SL and Aroma Global Spa (Chile), a privately held organizations group.

Institutional Review Board Statement: Not applicable.

Informed Consent Statement: Not applicable.

Data Availability Statement: Data sharing is not applicable to this article. 
Acknowledgments: The authors would like to thank Fundo El Junco, Melipilla, Chile, for their contribution in this review.

Conflicts of Interest: The authors declare no conflict of interest.

\section{References}

1. Koonaphapdeelert, S.; Aggarangsi, P.; Moran, J. (Eds.) Biomethane. Green Energy and Technology; Springer: Singapore, 2020; pp. 1-179. [CrossRef]

2. Langeveld, J.; Peterson, E. Feedstocks for Biogas Production: Biogas and Electricity Generation Potentials. In Biogas Fundamentals; Process; and Operation; Tabatabaei, M., Ghanavati, H., Eds.; Springer: Cham, Switzerland, 2018; pp. 35-49.

3. Khoshnevisan, B.; Tsapekos, P.; Alfaro, N.; Díaz, I.; Fernández-Polanco, M.; Rafiee, S.; Angelidaki, I. A review on prospects and challenges of biological $\mathrm{H}_{2} \mathrm{~S}$ removal from biogas with focus on biotrickling filtration and microaerobic desulfurization. Biofuel Res. J. 2017, 16, 741-750. [CrossRef]

4. Guidotti, T. Hydrogen sulfide intoxication. Handb. Clin. Neurol. 2015, 131, 111-133. [CrossRef]

5. Fabian-Wheeler, E.; Hile, M.; Murphy, D.; Hill, D.; Meinen, R.; Brandt, R.; Elliott, H.; Hofstetter, D. Operator Exposure to Hydrogen Sulfide from Dairy Manure Storages Containing Gypsum Bedding. J. Agric. Saf. Health 2017, 23, 9-22. [CrossRef] [PubMed]

6. Merico, E.; Grasso, F.; Cesari, D.; Decesari, S.; Belosi, F.; Manarini, F.; De Nuntiis, P.; Rinaldi, M.; Gambaro, A.; Morabito, E.; et al. Characterisation of atmospheric pollution near an industrial site with a biogas production and combustion plant in southern Italy. Sci. Total Environ. 2020, 717, 137220. [CrossRef] [PubMed]

7. Awe, O.; Zhao, Y.; Nzihou, A.; Pham Minh, D.; Lyczko, N. A Review of Biogas Utilisation; Purification and Upgrading Technologies. Waste Biomass Valorization 2017, 8, 267-283. [CrossRef]

8. Gabriel, D.; Colón, J.; Ramírez, M. Life cycle assessment of biofiltration. In From Biofiltration to Promising Options in Gaseous Fluxes Biotreatment. Recent Developments; New Trends; Advances; and Opportunities; Soreanu, G., Dumont, E., Eds.; Elsevier: Cambridge, MA, USA, 2020; pp. 89-108. [CrossRef]

9. Torres, R.; Maríun, D.; Rodero, M.; Pascual, C.; González-Sánchez, A.; de Godos Crespo, I.; Lebrero, R.; Muñoz Torre, R. Biogas treatment for $\mathrm{H}_{2} \mathrm{~S}, \mathrm{CO}_{2}$, and other contaminants removal. Life cycle assessment of biofiltration. In From Biofiltration to Promising Options in Gaseous Fluxes Biotreatment. Recent Developments; New Trends; Advances; and Opportunities; Soreanu, G., Dumont, E., Eds.; Elsevier: Cambridge, MA, USA, 2020; pp. 89-108. [CrossRef]

10. Rodríguez, G.; Dorado, A.; Fortuny, M.; Gabriel, D.; Gamisans, X. Biotrickling filters for biogas sweetening: Oxygen transfer improvement for a reliable operation. Process. Saf. Environ. Prot. 2014, 92, 261-268. [CrossRef]

11. Papurello, D.; Lanzini, A. SOFC single cells fed by biogas: Experimental tests with trace contaminants. Waste Manag. 2018, 72, 306-312. [CrossRef]

12. Saadabadi, S.; Thattai, A.; Fan, L.; Lindeboom, R.; Spanjers, H.; Aravind, P. Solid Oxide Fuel Cells fuelled with biogas: Potential and constraints. Renew. Energy 2019, 134, 194-214. [CrossRef]

13. Muñoz, R.; Meier, L.; Diaz, I.; Jeison, D. A review on the state of the art of physical/chemical and biological technologies for biogas upgrading. Rev. Environ. Sci. Biotechnol. 2015, 14, 727-759. [CrossRef]

14. Toledo-Cervantes, A.; Estrada, J.; Lebrero, R.; Muñoz, R. A comparative analysis of biogas upgrading technologies: Photosynthetic vs physical/chemical processes. Algal Res. 2017, 25, 237-243. [CrossRef]

15. Shareefdeen, Z. High-performance biofilters for air treatment applications. In From Biofiltration to Promising Options in Gaseous Fluxes Biotreatment. Recent Developments; New Trends; Advances; and Opportunities; Soreanu, G., Dumont, E., Eds.; Elsevier: Cambridge, MA, USA, 2020; pp. 111-127. [CrossRef]

16. Barbusiński, K.; Urbaniec, K.; Kasperczyk, D.; Thomas, M. Biofilters versus bioscrubbers and biotrickling filters: State-of-the-art biological air treatment. In From Biofiltration to Promising Options in Gaseous Fluxes Biotreatment. Recent Developments; New Trends; Advances; and Opportunities; Soreanu, G., Dumont, E., Eds.; Elsevier: Cambridge, MA, USA, 2020; pp. $29-51$.

17. Leson, G.; Winer, A. Biofiltration: An innovative air pollution control technology for VOC emissions. J. Air Waste Manag. Assoc. 1991, 41, 1045-1054. [CrossRef] [PubMed]

18. Le Borgne, S.; Baquerizo, G. Microbial Ecology of Biofiltration Units Used for the Desulfurization of Biogas. Chem. Eng. 2019, 3, 72. [CrossRef]

19. Gabaldón, C.; San-Valero, P.; Quijano, G. Current challenges and perspectives in gas fluxes biotreatment. In From Biofiltration to Promising Options in Gaseous Fluxes Biotreatment. Recent Developments; New Trends; Advances; and Opportunities; Soreanu, G., Dumont, E., Eds.; Elsevier: Cambridge, MA, USA, 2020; pp. 53-69.

20. Raboni, M.; Torretta, V. A modified biotrickling filter for nitrification-denitrification in the treatment of an ammonia-contaminated air stream. Environ. Sci. Pollut. Res. Int. 2016, 23, 24256-24264. [CrossRef] [PubMed]

21. López, L.; Mora, M.; Van der Heyden, C.; Baeza, J.A.; Volcke, E.; Gabriel, D. Model-Based Analysis of Feedback Control Strategies in Aerobic Biotrickling Filters for Biogas Desulfurization. Processes 2021, 9, 208. [CrossRef]

22. Wu, Y.; Ren, H.; Ding, L. Performance of an innovative polyethylene carrier biotrickling filter treating hydrogen sulphide gas. Huan Jing Ke Xue 2010, 31, 1451-1456. [PubMed]

23. Brito, J.; Valle, A.; Almenglo, F.; Ramírez, M.; Cantero, D. Progressive change from nitrate to nitrite as the electron acceptor for the oxidation of $\mathrm{H}_{2} \mathrm{~S}$ under feedback control in an anoxic biotrickling filter. Biochem. Eng. J. 2018, 139, 154-161. [CrossRef] 
24. Dumont, E. Determination of biofilter performances. In From Biofiltration to Promising Options in Gaseous Fluxes Biotreatment. Recent Developments; New Trends; Advances; and Opportunities; Soreanu, G., Dumont, E., Eds.; Elsevier: Cambridge, MA, USA, 2020; pp. 53-69.

25. Valle, A.; Fernández, M.; Ramírez, M.; Rovira, R.; Gabriel, D.; Cantero, D. A comparative study of eubacterial communities by PCR-DGGE fingerprints in anoxic and aerobic biotrickling filters used for biogas desulfurization. Bioprocess. Biosyst. Eng. 2018, 41, 1165-1175. [CrossRef]

26. Almenglo, F.; Ramírez, M.; Gómez, J.; Cantero, D. Operational conditions for start-up and nitrate-feeding in an anoxic biotrickling filtration process at pilot scale. Chem. Eng. J. 2016, 285, 83-91. [CrossRef]

27. Ben Jaber, M.; Couvert, A.; Amrane, A.; Rouxel, F.; Le Cloirec, P.; Dumont, E. Biofiltration of high concentration of $\mathrm{H}_{2} \mathrm{~S}$ in waste air under extreme acidic conditions. New Biotechnol. 2017, 33, 136-143. [CrossRef] [PubMed]

28. Cruz-García, B.; Geronimo-Meza, A.; Martínez-Lievana, C.; Arriaga, S.; Huante-González, Y.; Aizpuru, A. Biofiltration of high concentrations of methanol vapors: Removal performance; carbon balance and microbial and fly populations. J. Chem. Technol. Biotechnol. 2019, 94, 1925-1936. [CrossRef]

29. Fernández, M.; Ramírez, M.; Pérez, R.; Gómez, J.; Cantero, D. Biofiltration of $\mathrm{H}_{2} \mathrm{~S}$ in biogas with Thiobacillus denitrificans under anoxic conditions. EcoSTP. EcoTechnologies for Wastewater Treatment. In Proceedings of the IWA International Conference, Santiago de Compostela, Spain, 27-28 June 2012; p. 53.

30. Tayar, S.; Guerrero, R.; Hidalgo, L.; Bevilaqua, D. Evaluation of Biogas Biodesulfurization Using Different Packing Materials. ChemEngineering 2019, 3, 27. [CrossRef]

31. Montebello, A.; Fernández, M.; Almenglo, F.; Ramírez, M.; Cantero, D.; Baeza, M.; Gabriel, D. Simultaneous methylmercaptan and hydrogen sulfide removal in the desulfurization of biogas in aerobic and anoxic biotrickling filters. Chem. Eng. J. 2012, 200, 237-246. [CrossRef]

32. Fernández, M.; Ramírez, M.; Pérez, R.; Gómez, J.; Cantero, D. Hydrogen sulphide removal from biogas by an anoxic biotrickling filter packed with Pall rings. Chem. Eng. J. 2013, 225, 456-463. [CrossRef]

33. Romero, A.; Rodríguez, M.; Andrès, Y.; Dumont, E. Steady- and transient-state $\mathrm{H}_{2} \mathrm{~S}$ biofiltration using expanded schist as packing material. New Biotechnol. 2013, 30, 210-218. [CrossRef] [PubMed]

34. Fernández, M.; Ramírez, M.; Gómez, J.; Cantero, D. Biogas biodesulfurization in an anoxic biotrickling filter packed with open-pore polyurethane foam. J. Hazard. Mater. 2014, 264, 529-535. [CrossRef]

35. Almenglo, F.; Bezerra, T.; Lafuente, J.; Gabriel, D.; Ramirez, M.; Cantero, D. Effect of gas-liquid flow pattern and microbial diversity analysis of a pilot-scale biotrickling filter for anoxic biogas desulfurization. Chemosphere 2016, 157, 215-223. [CrossRef] [PubMed]

36. Lebrero, R.; Toledo-Cervantes, A.; Muñoz, R.; del Nery, V.; Foresti, E. Biogas upgrading from vinasse digesters: A comparison between an anoxic biotrickling filter and an algal-bacterial photobioreactor. J. Chem. Technol. Biotechnol. 2016, 91, 2488-2495. [CrossRef]

37. Li, X.; Jiang, X.; Zhou, Q. Effect of S/N Ratio on the Removal of Hydrogen Sulfide from Biogas in Anoxic Bioreactors. Appl. Biochem. Biotechnol. 2016, 180, 930-944. [CrossRef]

38. Pirolli, M.; da Silva, M.; Mezzari, M.; Michelon, W.; Prandini, J.; Moreira-Soares, H. Methane production from a field-scale biofilter designed for desulfurization of biogas stream. J. Environ. Manag. 2016, 177, 161-168. [CrossRef] [PubMed]

39. Ziemiński, K.; Kopycki, W. Impact of Different Packing Materials on Hydrogen Sulfide Biooxidation in Biofilters Installed in the Industrial Environment. Energy Fuel 2016, 30, 9386-9395. [CrossRef]

40. Ben Jaber, M.; Couvert, A.; Amrane, A.; Le Cloirec, P.; Dumont, E. Hydrogen sulfide removal from a biogas mimic by biofiltration under anoxic conditions. J. Environ. Chem. Eng. 2017, 5, 5617-5623. [CrossRef]

41. Brito, J.; Almenglo, F.; Ramírez, M.; Gómez, J.; Cantero, D. PID control system for biogas desulfurization under anoxic conditions. J. Chem. Technol. Biotechnol. 2017, 92, 2369-2375. [CrossRef]

42. López, L.; Brito, J.; Mora, M.; Almenglo, F.; Baeza, J.; Ramírez, M.; Lafuente, J.; Cantero, D.; Gabriel, D. Feedforward control application in aerobic and anoxic biotrickling filters for $\mathrm{H}_{2} \mathrm{~S}$ removal from biogas. J. Chem. Technol. Biotechnol. 2018, 93, 2307-2315. [CrossRef]

43. Khanongnuch, R.; Di Capua, F.; Lakaniemi, A.; Rene, E.; Lens, $\mathrm{P} . \mathrm{H}_{2} \mathrm{~S}$ removal and microbial community composition in an anoxic biotrickling filter under autotrophic and mixotrophic conditions. J. Hazard. Mater. 2019, 367, 397-406. [CrossRef]

44. Flemming, H.; Wingender, J.; Szewzyk, U.; Steinberg, P.; Rice, S.; Kjelleberg, S. Biofilms: An emergent form of bacterial life. Nat. Rev. Microbiol. 2016, 14, 563-575. [CrossRef] [PubMed]

45. Yin, W.; Wang, Y.; Liu, L.; He, J. Biofilms: The Microbial “Protective Clothing” in Extreme Environments. Int. J. Mol. Sci. 2019, $20,3423$. [CrossRef]

46. Karygianni, L.; Ren, Z.; Koo, H.; Thurnheer, T. Biofilm Matrixome: Extracellular Components in Structured Microbial Communities. Trends Microbiol. 2020, 28, 668-681. [CrossRef] [PubMed]

47. Omri, I.; Bouallagui, H.; Aouidi, F.; Godon, J.; Hamdi, M. $\mathrm{H}_{2} \mathrm{~S}$ gas biological removal efficiency and bacterial community diversity in biofilter treating wastewater odor. Bioresour. Technol. 2011, 102, 10202-10209. [CrossRef]

48. Ramírez, M.; Fernández, M.; Granada, C.; Le Borgne, S.; Gómez, J.; Cantero, D. Biofiltration of reduced sulphur compounds and community analysis of sulphur-oxidizing bacteria. Bioresour. Technol. 2011, 102, 4047-4053. [CrossRef] [PubMed] 
49. López, L.; Bezerra, T.; Mora, M.; Lafuente, J.; Gabriel, D. Influence of trickling liquid velocity and flow pattern in the improvement of oxygen transport in aerobic biotrickling filters for biogas desulfurization. J. Chem. Technol. Biotechnol. 2016, 91, 1031-1039. [CrossRef]

50. Pu, S.; Liu, Z.; Yang, F.; Long, D.; Liu, W.; Wang, H.; Huang, K.; Huang, X. Comparative study on the removal efficiency of hydrogen sulfide $\left(\mathrm{H}_{2} \mathrm{~S}\right)$ using three different packings. J. Air Waste Manag. Assoc. 2018, 68, 900-908. [CrossRef] [PubMed]

51. Maier, R. Biogeochemical cycling. In Environmental Microbiology, 3rd ed.; Pepper, I., Gerba, C., Gentry, T., Eds.; Elsevier: San Diego, CA, USA, 2015; pp. 339-373.

52. Valdebenito-Rolack, E.; Ruiz-Tagle, N.; Abarzúa, L.; Aroca, G.; Urrutia, H. Characterization of a hyperthermophilic sulphuroxidizing biofilm produced by archaea isolated from a hot spring. Electron. J. Biotechnol. 2017, 25, 58-63. [CrossRef]

53. Valdebenito-Rolack, E.; Araya, T.; Abarzua, L.; Ruiz-Tagle, N.; Sossa, K.; Aroca, G.; Urrutia, H. Thiosulphate oxidation by Thiobacillus thioparus and Halothiobacillus neapolitanus strains isolated from the petrochemical industry. Electron. J. Biotechnol. 2011, 14, 1-9. [CrossRef]

54. Almenglo, F.; Ramírez, M.; Cantero, D. Application of Response Surface Methodology for $\mathrm{H}_{2} \mathrm{~S}$ Removal from Biogas by a Pilot Anoxic Biotrickling Filter. ChemEngineering 2019, 3, 66. [CrossRef]

55. Rodero, M.; Ángeles, R.; Marín, D.; Díaz, I.; Colzi, A.; Posadas, E.; Lebrero, R.; Muñoz, R. Biogas Purification and Upgrading Technologies. In Biogas Fundamentals; Process; and Operation; Tabatabaei, M., Ghanavati, H., Eds.; Springer: Cham, Switzerland, 2018; pp. 239-276.

56. Vikrant, K.; Kailasa, S.; Tsang, D.; Lee, S.; Kumar, P.; Giri, B.; Singh, R.; Kim, K. Biofiltration of hydrogen sulfide: Trends and challenges. J. Clean. Prod. 2018, 187, 131-147. [CrossRef]

57. Muyzer, G.; de Waal, E.; Uittierlinden, A. Profiling of complex microbial populations by denaturing gradient gel electrophoresis analysis of polymerase chain reaction-amplified genes coding for 16S rRNA. Appl. Environ. Microbiol. 1993, 59, 695-700. [CrossRef]

58. Ralebitso-Senior, T.; Senior, E.; Di Felice, R.; Jarvis, K. Waste gas biofiltration: Advances and limitations of current approaches in microbiology. Environ. Sci. Technol. 2012, 46, 8542-8573. [CrossRef]

59. Spohr, G.; Mirault, M.; Imaizumi, T.; Scherrer, K. Molecular-weight determination of animal-cell RNA by electrophoresis in formamide under fully denaturing conditions on exponential polyacrylamide gels. Eur. J. Biochem. 1976, 62, 313-322. [CrossRef] [PubMed]

60. Muyzer, G.; Teske, A.; Wirsen, C.; Jannasch, H. Phylogenetic relationships of Thiomicrospira species and their identification in deep-sea hydrothermal vent samples by denaturing gradient gel electrophoresis of $16 \mathrm{~S}$ rDNA fragments. Arch. Microbiol. 1995, 164, 164-172. [CrossRef]

61. Khanongnuch, R.; Di Capua, F.; Lakaniemi, A.; Rene, E.; Lens, P. Effect of N/S ratio on anoxic thiosulfate oxidation in a fluidized bed reactor: Experimental and artificial neural network model analysis. Process. Biochem. 2018, 68, 171-181. [CrossRef]

62. Zhang, J.; Ma, G.; Deng, Y.; Dong, J.; Van Stappen, G.; Sui, L. Bacterial Diversity in Bohai Bay Solar Saltworks; China. Curr. Microbiol. 2016, 72, 55-63. [CrossRef]

63. Beck, J.; Benson, D.; Coleman, J.; Hoeppner, M.; Johnson, M.; Maglott, D.; Mizrachi, I.; Morris, R.; Ostell, J.; Pruitt, K.; et al. (Eds.) The NCBI Handbook, 2nd ed.; National Center for Biotechnology Information: Bethesda, MD, USA, 2019; pp. 1-434. Available online: https: / / www.ncbi.nlm.nih.gov /books /NBK143764/ (accessed on 16 March 2021).

64. Altschul, S.; Madden, T.; Schaffer, A.; Zhang, J.; Zhang, Z.; Miller, W. Gapped Blast and PSI BLAST: A new generation of protein database search programs. Nucleic Acids Res. 1997, 25, 3389-3402. [CrossRef] [PubMed]

65. Margulies, M.; Egholm, M.; Altman, W.; Attiya, S.; Bader, J.; Bemben, L.; Berka, J.; Braverman, M.; Chen, Y.; Chen, Z.; et al. Genome sequencing in microfabricated high-density picolitre reactors. Nature 2005, 437, 376-380. [CrossRef] [PubMed]

66. Saitou, N.; Nei, M. The neighbor-joining method: A new method for reconstructing phylogenetic trees. Mol. Biol. Evol. 1987, 4, 406-425. [CrossRef] [PubMed]

67. Tamura, K.; Nei, M.; Kumar, S. Prospects for inferring very large phylogenies by using the neighbor-joining method. Proc. Natl. Acad. Sci. USA 2004, 101, 11030-11035. [CrossRef]

68. Elías, A.; Barona, A.; Gallastegi, G.; Rojo, N.; Gurtubay, L.; Ibarra-Berastegi, G. Preliminary acclimation strategies for successful startup in conventional biofilters. J. Air Waste Manag. Assoc. 2010, 60, 959-967. [CrossRef] [PubMed]

69. Tu, X.; Guo, J.; Yang, Y.; Feng, R.; Sun, G.; Li, J. Biofilms formed within the acidic and the neutral biotrickling filters for treating $\mathrm{H}_{2} \mathrm{~S}$-containing waste gases. RSC Adv. 2017, 7, 25475-25482. [CrossRef]

70. Herigstad, B.; Hamilton, M.; Heersink, J. How to optimize the drop plate method for enumerating bacteria. J. Microbiol. Methods 2001, 44, 121-129. [CrossRef]

71. Baron, F.; Cochet, M.; Ablain, W.; Grosset, N.; Madec, M.; Gonnet, F.; Jan, S.; Gautier, M. Rapid and cost-effective method for micro-organism enumeration based on miniaturization of the conventional plate-counting technique. Le Lait 2006, 86, 251-257. [CrossRef]

72. Vergara-Fernández, A.; Scott, F.; Moreno-Casas, P. Biofiltration of volatile organic compounds and polycyclic aromatic hydrocarbons. In From Biofiltration to Promising Options in Gaseous Fluxes Biotreatment. Recent Developments; New Trends; Advances; and Opportunities; Soreanu, G., Dumont, E., Eds.; Elsevier: Cambridge, MA, USA, 2020; pp. 53-69.

73. Rahul; Mathur, A.K.; Bala, S.; Majumder, C. Modelling and computational fluid dynamic behaviour of a biofilter treating benzene. Bioresour. Technol. 2012, 125, 200-207. [CrossRef] 
74. Ramirez-Lopez, E.; Corona-Hernandez, J.; Avelar-Gonzalez, F.; Omil, F.; Thalasso, F. Biofiltration of methanol in an organic biofilter using peanut shells as medium. Bioresour. Technol. 2010, 101, 87-91. [CrossRef]

75. Nikiema, J.; Heitz, M. The Use of Inorganic Packing Materials during Methane Biofiltration. Int. J. Chem. Eng. 2010, 2010. [CrossRef]

76. Zhu, R.; Li, S.; Bao, X.; Dumont, É. Comparison of biological $\mathrm{H}_{2} \mathrm{~S}$ removal characteristics between a composite packing material with and without functional microorganisms. Sci. Rep. 2017, 7, 42241. [CrossRef] [PubMed]

77. Rattanapan, C.; Ounsaneha, W. Removal of Hydrogen Sulfide Gas using Biofiltration-A Review. Walailak J. Sci. Tech. 2012, 9, 9-18.

78. Okoro, O.; Sun, Z. Desulphurisation of Biogas: A Systematic Qualitative and Economic-Based Quantitative Review of Alternative Strategies. ChemEngineering 2019, 3, 76. [CrossRef]

79. Ramírez, M. Special Issue “Advances in Biogas Desulfurization”. ChemEngineering 2020, 4, 17. [CrossRef]

80. López, L.; Dorado, A.; Mora, M.; Gamisans, X.; Lafuente, J.; Gabriel, D. Modeling an aerobic biotrickling filter for biogas desulfurization through a multi-step oxidation mechanism. ChemEngineering 2016, 294, 447-457. [CrossRef]

81. Almenglo, F.; Ramírez, M.; Gómez, J.; Cantero, D.; Gamisans, X.; Dorado, A. Modeling and control strategies for anoxic biotrickling filtration in biogas purification. J. Chem. Technol. Biotechnol. 2016, 91, 1782-1793. [CrossRef] 